مجلة العلوم القانونية / كلية القانون - جامعة بغداد العدد الخاص الثالث- الجزع الثاني /

$$
r+1 V
$$

\title{
التقاضي الضريبي كضمانة دستورية للمكلف بدفع الضريب
}

أ.م.د. محمد علوم محمد

كلية القانون - جامعة بغداد

طالبة الماجستير سولاف فيصل خضير

كلية القانون - الجامعة المستنصيرية

ملخص

تناولنا في هذه الدراسة بالتفصيل موضوع حق التقاضي في دستور جمهورية العراق

النافذ وبعض دساتير الدول العبية والاجنبية التي على الرغم من الاختلاف بينهما في حجم

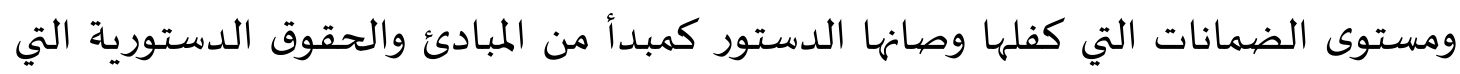
ترتبط ارتباطا مباشرا بالشؤون الضرائبية . 
مجلة العلوم القانونية / كلية القانون - جامعة بخداد العدد الخاص الثالث- الجزع الثاني /

ولكثرة الخروقات والعدوان على تلك المبادئ والحقوق ومنها حق التقاضي ، فما كان منا الا ان ندعو المشرع العراقي الى تعديل هذه القوانين الضريبية بالشكل الذي يتم فيها رفع الانتهاكات

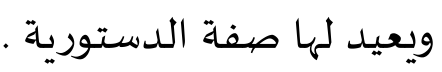

\section{Abstract}

In this study we address in detail a collection of constitutional principles and rights directly to tax affairs i.e. the principles of tax legality, the right of tax equality and tax justice, the right of prosecution within the valid 2005 constitution of the republic of Iraq the and the comparative constitutions. Despite the difference between them in the level and size of these rights and principles, they all are guaranteed and maintained by them, yet the Iraqi tax laws came with many violations, penetrations and aggression on those principles and right such as the Iraqi income tax law no.113 for the year 1982 as amended, so we have to call the Iraqi taxation legislator to amend this law in the form that eliminates all these violations and returns back its constitutional character which it lost for a long period of time.

Taxes are one of important financial policy instruments through which the state endeavors to provide the financial revenues necessary to finance its public expenditures as well as using them in directing the economy in the way targeted by the state for the purpose of achieving the economy and stability.

Although Iraq is one of the most ancient state in the region in issuing tax legislations and law, the role of these legislations and law in financing the state's expenditures and achieving its economic and social goals is limited in view of Iraq. 
مجلة العلوم القانونية / كلية القانون - جامعة بغداد العدد الخاص الثالث- الجزء الثاني / r.IV

\section{المقدمة}

نظرا لما يحتله موضوع التقاضي الضريبي كضمانة دستورية للمكلف من اهمية كبيرة من بين

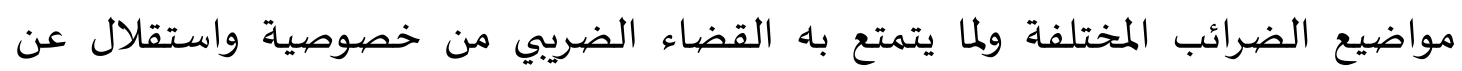
القضاء سواء المدني او الاداري ، وهذا ينبع من الذاتية الخاصة التي يتمتع بها القانون

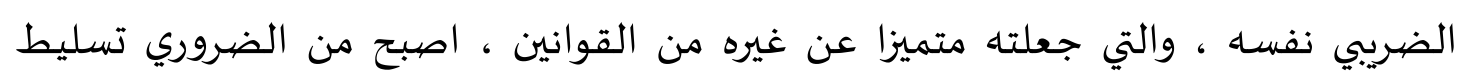

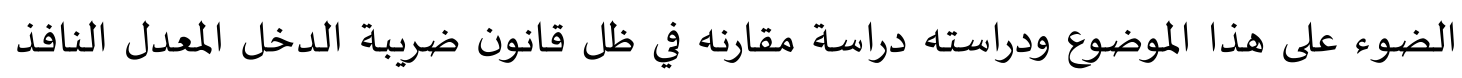

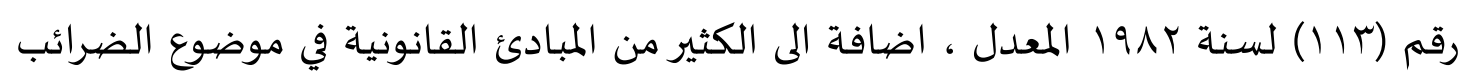
تم ترسيخها بناءا على قرارات واحكام المحاكم التي ساهمت بدور كبير ومباشر في ارساء هذه المبادئ .

والوقوف على المشاكل التي يثيرها والمعوقات التي تعترضها والضمانات التي تكفل نجاحه ، واثراء البحث وتحقيق الغاية العلمية والعملية قامت الباحثه بالاطلاع على مجموعة المراجع

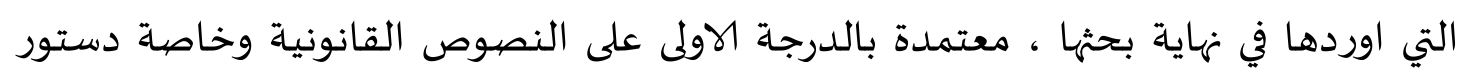

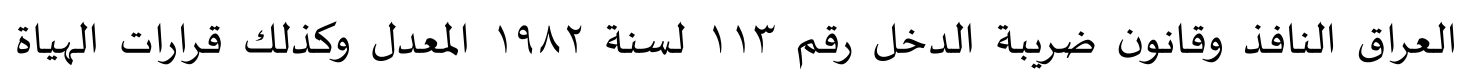
الاستئنافية والتمييزية في العراق . وقد تناولت الباحثة الموضوع على النحو التالي :.

اولا :اهمية الدراسة : القاء الضوء على اهمية وجود قضاء ضريبي متخصص لمصلحة

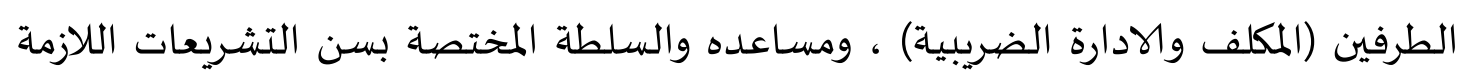

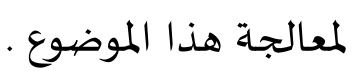
ثانيا : مشكلة الدراسة : نقص التشريع في مجال الضرائب بشكل عام وتناثره في اكثر من

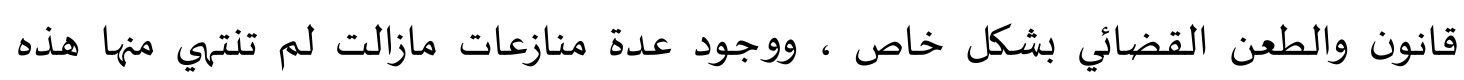

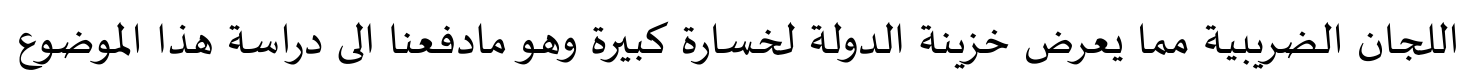


مجلة العلوم القانونية / كلية القانون - جامعة بغداد العدد الخاص الثالث- الجزع الثاني / r. IV

بغية تفصيل احامه ومعرفة مدى توافقه مع قوانين الدول العربية والاجنبية في ظل اخر تطورات .

ثالثا : منهجية الدراسة : سنعتمد في دراستنا النهج التحليلي المقارن من خلال قانون ضريبة الدخل العراقي لعام ra19 المعدل والقوانين العراقية السابقة والقوانين والانظمة ذات العلاقة اضافة الى القوانين العربية والاجنبية والاطلاع على الدراسات المقارنة لبعض الدول والتي تبحث في نفس الموضوع

اذ سنعمد الى تحليل النصوص القانونية في التشريعات الضريبية العراقية ونقارنها مع

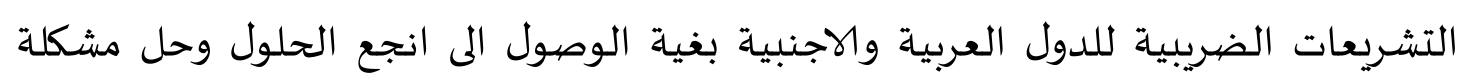
هذه الدراسة .

رابعا : هيكلية الدراسة : في سبيل ذلك سنقسم هذه الدراسة على مبحثين في المبحث الول مفهوم القضاء الضريبي واهميته وفي المبحث الثاني سنتناول - القضاء الضريبي في التشريع المقارن ومراحل الطعن القضائي في العراق لنختم البحث بطره اهم الاستنتاجات والتوصيات والله ولي

\section{المبحث الاول}

\section{ماهية القضياء الضريبي واهميته}

يلعب القضاء دورا هاما في ارساء المبادئ القانونية وازالة اي غموض يكتنف التشريعات

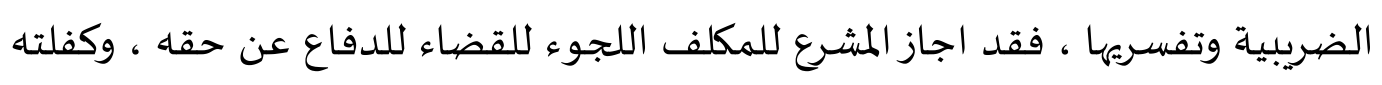
كافة الشرائع والقوانين والدساتير وضمنت حيادتيه واستقلاله لتحقيق العدل .

فالقضاء الضريبي يسعى الى سيادة القانون واحكامه في الميدان الضريبي كما يسعى الى حماية

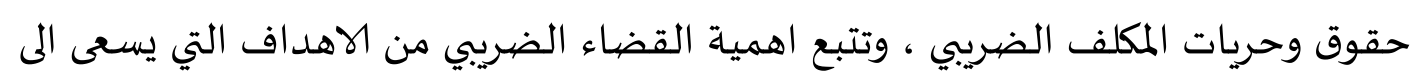


مجلة العلوم القانونية / كلية القانون - جامعة بغداد العدد الخاص الثالث- الجزع الثاني /

تحقيقها ، وهي كثيرة وحيوية في حياة كل من الفرد والدولة ، وبغية تسليط الضوء على موضوع القضاء الضريبي واهميته سوف نتناوله في مطلبين نكرس الاول لبيان مفهوم القضاء

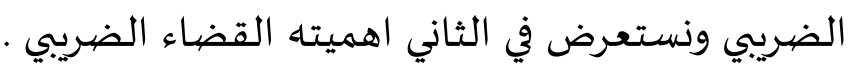

$$
\text { المطلب الاول }
$$

\section{مفهوم القضياء الضريبي}

ان القضاء الضريبي شانه شان جهات القضاء الاخرى يختص برفع النزاع الذي ينظر فيه وكانه قضاء متخصص بالفصل بالخصومه الضريبية ، وبغية تحديد مفهوم هذا القضاء يقتضي بيان امرين : الفرع الوول :. تعريف القضاء الضريبي الفرع الثاني :. الاسس التي يشاد علهها القضاء الضريبي الفرع الاول تعريف القضاء الضريبي

ان مصطلح القضاء الضريبي يتكون من مفردتين ، لذا ابتداءا يجب ان نبين بالقضاء ثم

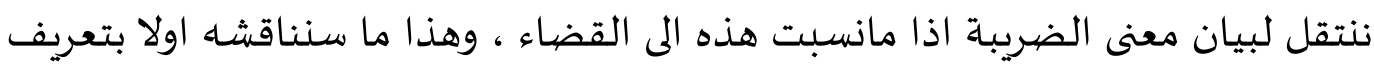
القضاء والضريبة لغة ، ثم تعريف القضاء الضريبي اصطلاحسا .

$$
\text { اولا : تعريف القضياء والضريبة لغة }
$$

ان القضاء في اللغة يعد من الالفاظ ذات المعاني المتعدده ، وقد ورد في معاجم اللغة ، انه يعني الحسم والقطع والانهاء ، وقد عرفت المادة ( IV^I) من مجلة الاحكام العدلية : (القضاء ياتي بمعنى الحكم وياتي بمعنى الحاكمية ( جهاز القضاء ) والقضاة هم الذين

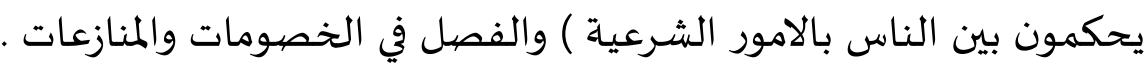


مجلة العلوم القانونية / كلية القانون - جامعة بغداد العدد الخاص الثالث- الجزء الثاني /

وسمي القاضي حاكما لمنعاه الظالم من ظلمها ، اي حكم واوجب ، وانه الحكم ، واصله قضائي ، لاناه من قضيت ، والجمع الاقضية والقضية مثله ، والجمع القضايا ، ويراد

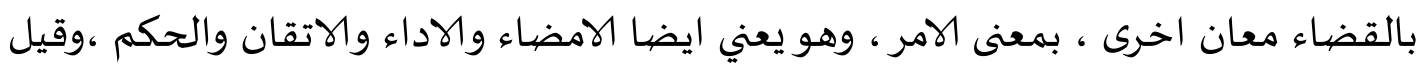

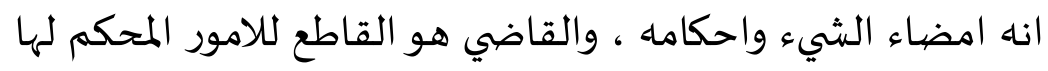
ثانيا : تعريف القضاء الضريبي اصطلاحا

لابد من التعريف بالقضاء بعيدا عن الاتجاهات الفقهية التي قيلت في تعريف القضاء

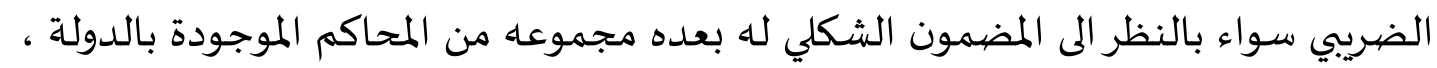

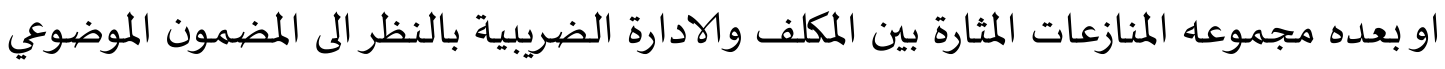
، او بحسبانه المبادئ القانونية التي تستخلص من استقرار المحاكم الدائبة على اتباعها .

تعريف القضاء على انه مجموعاه المبادئ القانونية التي تستخلص من استقرار المحاكم على اتباعها والحكم عليها ، وانه حق يتيح لكل فرد وقع اعتداء على حق من حقوقه ان يلجا الى لي القضاء لرد ذلك الاعتداء والانتصاف لنفسه ممن ظلمها وسلبه حقه ، وانها مجموعاه الاحكام او القرارات التي تصدرها المحاكم في المنازعات التي تعرض عليها .

وهو الاخبار عن حكم شرعي على سبيل الالزام اذ هو فصل الخصيومات وقطع المنازعات على على وجه الخصوص او قول ملزم صادر عن ولايه عامه .

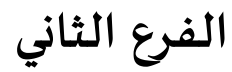

\section{الاسس التي يشـاد عليها القضياء الضريبي}

يقول الاستاذ محمد عصفور - ان مقومات القضاء عصببه متماسكاء لذلك لاتقوم سلطة

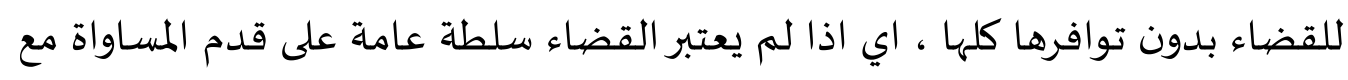
السلطتين التشريعية والتنفيذية واذا لم يكفل لهذه السلطة حيادها واطلاع المختصين بشؤنها ، وعليه فان المبادىء الجوهرية التي يجب ان يشاد علها كل قضاء ، ومنها القضاء الضريبي ، 
مجلة العلوم القانونية / كلية القانون - جامعة بغداد العدد الخاص الثالث- الجزء الثاني /

تتحدد في ثلاثة كالاتي : - n

اولا : مبدا استقلال القضاء الضريبي

ثانيا : مبدا حياد القضاء الضريبي

ثالثا : مبدا تخصص القضاء الضريبي

اولا : مبدا استقلال القضاء الضريبي

يرى فقهاء القانون الدستوري ان استقلال القضاء نتيجة طبيعية لمبدا الفصل بين السلطات وضمان لتحقيق الحرية ، وان السلطة القضائية مستقلة وتقوم بالفصل بين الخصيومات وتطبيق القوانين على المنازعات التي تنشا بين الاشخاص وتوقيع الجزاءات على من يخالف

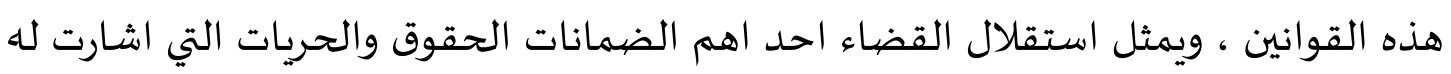

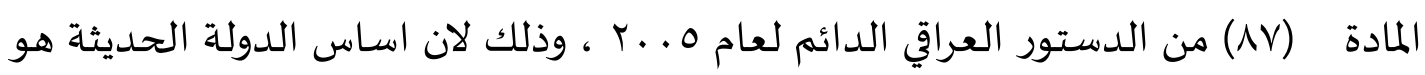

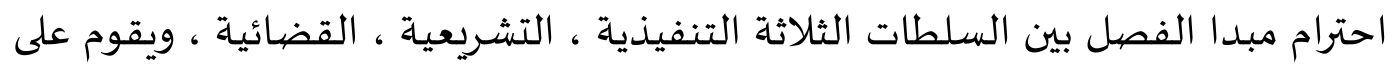

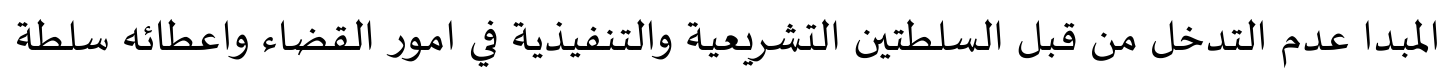

$$
\text { دانيا : مبدورياه منفصله ومستقله عنهم . }
$$

القضاء بطبيعتاه يتصف بالحياد وهو ينظر بتلك الصفة في كافة القضايا المعروضة عليه ولكافة الاجراءات الواجب اتباعها بغض النظر عن طبيعة تلك القضايا او اطرافها او مركزهم

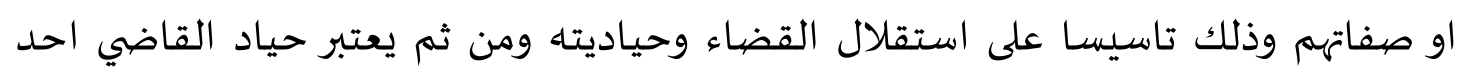

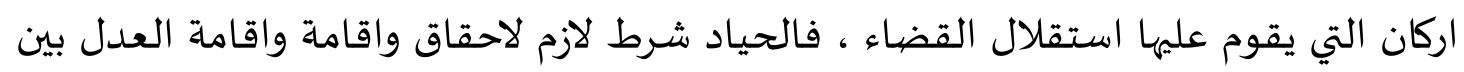
الناس . 
مجلة العلوم القانونية / كلية القانون - جامعة بغداد العدد الخاص الثالث- الجزء الثاني / $r+1 \mathrm{~V}$

يمثل القضاء الملاذ والحصن لحماية الحقوق على اختلاف اشكالها ، ومن اهم حقوق الانسان في نظام قضائي نزيها ومستقل اي وجود قضاء عادل ومستقل وان تتوفر لاطراف الخصومة

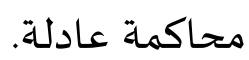

وحياد القاضي مفهوم اخلاقي يدخل في صميم المفاهيم القانونية ، ويكمن في جوهر العمل

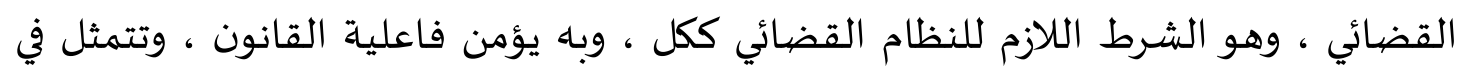

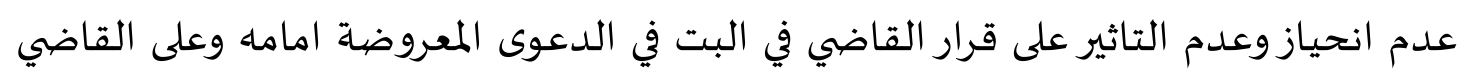

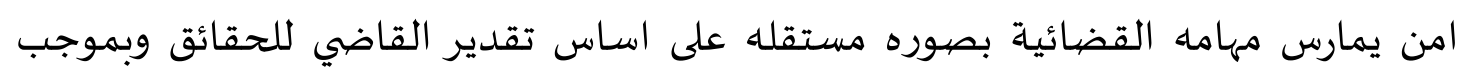

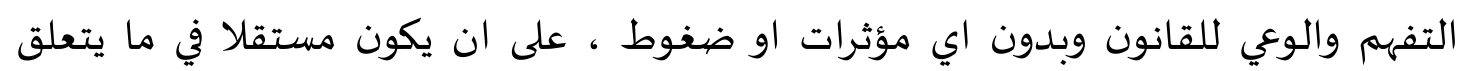

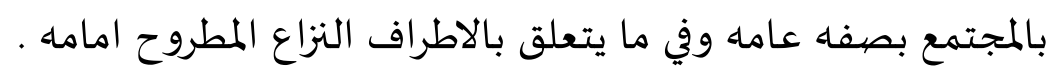

ان حياد القضاء من المبادئ الدستورية العامة اذا لم ينص علهها الدستور صراحة فهذا المبدا يمكن ان نستخلصها من مبدا استقلال القضاء على اعتبار ان هذا الاستقلال يقرر

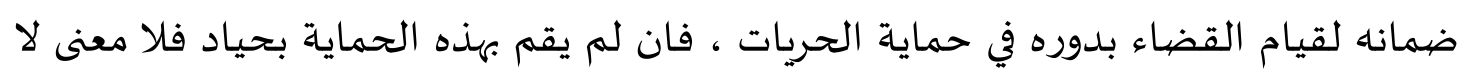
ستقلاله . - n ثالثا : مبدا تخصص القضياء الضريبي : ان هذا المبدا يمثل اكبر ضمانه لحقوق المكلفين وتحافظ على مبدا المشروعية من كل اعتداء

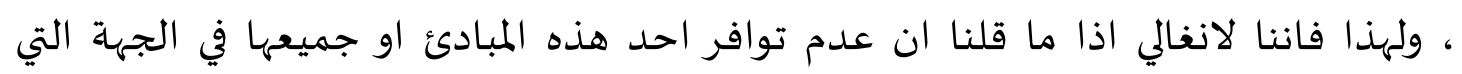
تفصل في النزاع بين المكلف والادارة الضريبية يعدم صفة القضاء فيها وفقا للمعنى الحقيقي لمفهوم القضاء ، على اعتبار القضاء فن من نوع خاص لا يمارساء الا المتخصصيون ، وقد جرى لمريل

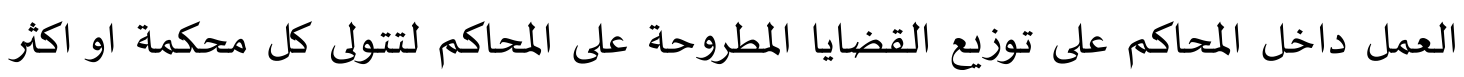
النظر في نوع منها ويستمد قوامه من التدريب والتاهيل والممارسة والخبرة والتجربة . فهو محل اتفاق بين معظم رجال الفقه العربي والفرنسي موضحين مدى الاهمية التي يشغلها كل مبدا بالنسبة للقضاء الضريبي ان وجود قاض متخصص في فرع معان معين من فروع القانون 
مجلة العلوم القانونية / كلية القانون - جامعة بغداد العدد الخاص الثالث- الجزء الثاني / r. IV

يمكنه من متابعة ما يطرا من تعديلات الامر الذي ييسر ويسهل له سرعة الفصل فيما يثور

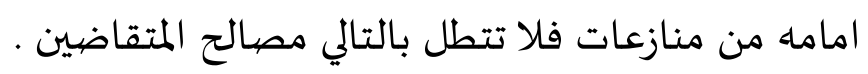

$$
\text { المطلب الثاني }
$$

\section{اهمية القضياء الضريبي}

تتبع اهمية القضاء الضريبي من كون موضوع الضريبه حديثا نسبيا و بالتالي فقوانينه حديثه مقارنه مع القوانين الاخرى ، و غالبا ما تكون مواد يعترها الغموض ،اضيافه الى ما تثيره

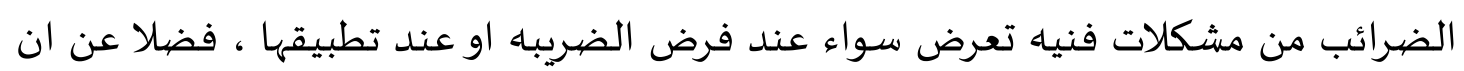

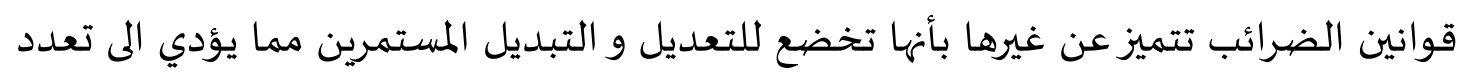
النصوص و تعقيدها و صعبوبة تطبيقها و تفسيرها ، و بالتالي جهل المكلفين في كثير من الاحيان بها يؤدي ، مما يؤدي الى نشوء نزاعات و خلافات بين الاداره الضريبيه و المكلفين ونهين و سنتناول في هذا المطلب بشيء من التفصيل في ثمانية فروع على النحو الاتي :الفرع الاول :- دور القضاء الضريبي في الحفاض على مبداء المشروعيه الفرع الثاني:- مسعى القضاء الضريبي في الدفاع عن حقوق المكلفين الطاعنين الفرع الثالث :- دور القضاء الضريبي في رقابة نشاط الاداره الضريبيه الفرع الرابع :- اهمية القضاء الضريبي في اكمال النقص التشريعي الفرع الخامس :- دور القضاء الضريبي في اكمال النقص التشريعي الفرع السادس :- دور القضاء الضريبي في ضمان الحريه الماليه الفرع السابع عمل القضاء الضريبي في تاصيل مباديء القانون الضريبي 
مجلة العلوم القانونية / كلية القانون - جامعة بغداد العدد الخاص الثالث- الجزء الثاني / r. IV

الفرع الثامن :- دور القضاء الضريبي في تحقيق التوازن بين مصالح المكلفين و الاداره الضريبيه

\section{الفرع الاول}

\section{دور القضاء الضريبي في الحفاظ على مبداء المشروعيه}

ان الضمانه الاساسيه التي تحمي الافراد من تعسف الاداره و تحكمها ، انما تتركز على

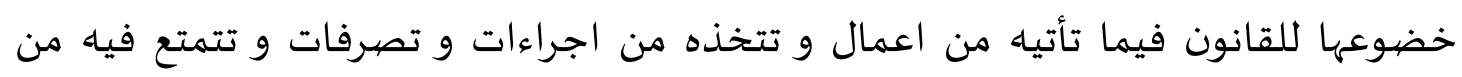

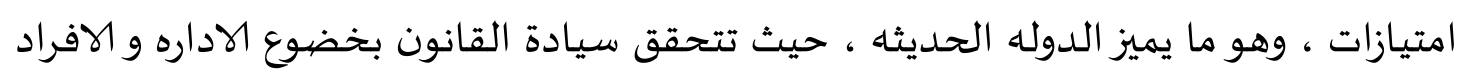
بصفه عامه للقانون بحيث تكون تصرفاتها السلبيه و الايجابيه في دائرة حدود النظام

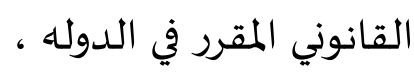

فالسلطه التشريعياه يتعين ان تخضع للدستور ، و ان تباشر و ظيفتها في حدود احكامه ، كما

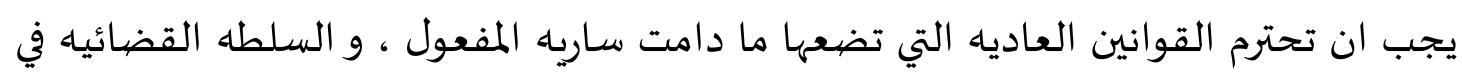
نطاق تطبيق القانون على المنازعات المعروضيه امامها يتعين عليها ان لا تخالف احكام القانون

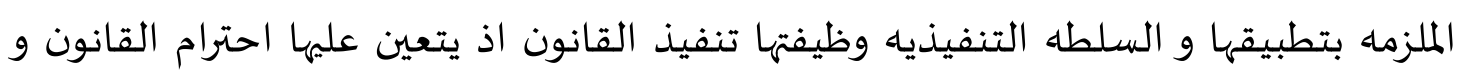
ان تلتزم حدودها سواء مباشرتها لوظيفتها الحكوميه و في اتمام لوظيفتها الاداريه

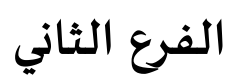

\section{مسعى القضياء الضريبي في الدفاع عن حقوق المكلفين}

ان حق التقاضي يعتبر من الحقوق الاساسيه لحقوق الانسان او الحقوق الطبيعيه القانونيه

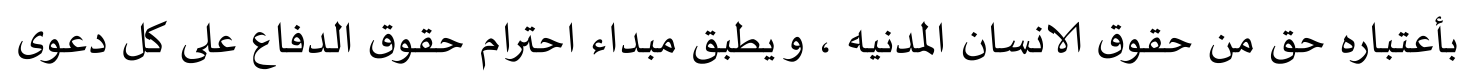
قضائيه اي كان نوعها ، و الا فأن الحكم الذي تصددره المحكماه يكون منعدما ولا يكون قرارا

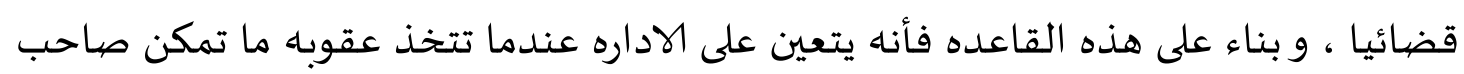
العلاقه من تقديم دفاعه و ابداء ملاحظاته و منحه الوقت الكافي لتحضير دفاعه ، 
مجلة العلوم القانونية / كلية القانون - جامعة بغداد العدد الخاص الثالث- الجزء الثاني / r.IV

و تعد امتيازات السلطه الاداريه مزايا اجرائيه تتدخل في مختلف وسائل ممارسة الوظائف

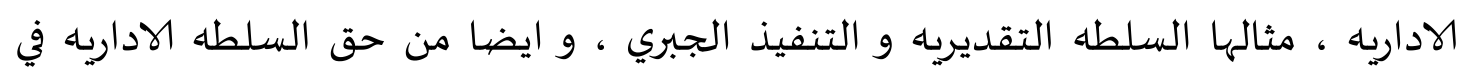

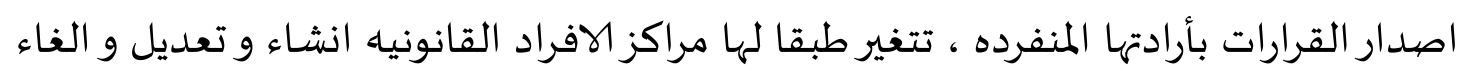

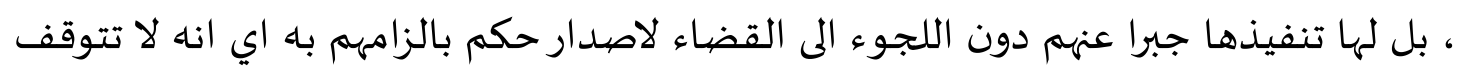

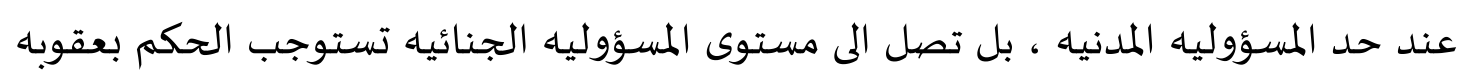

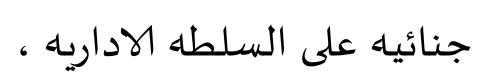

\section{الفرع الثالث}

\section{دور القضياء الضريبي في رقابة نشاط الاداره الضريبيه}

تعد الرقابه عملا يدخل في صميم السلطه القضائيه التي تلتزم بتطبيق القانون تطبيقا سليما حيث تملك الاداره سلطه تقدير الضريبه بصوره تلقائيه و تفرض عقوبات عند مخالفت المكلف للالتزامات الضريبيه لذا للقاضي الضريبي ان يتحرى و يتحقق عن حدود السلطه

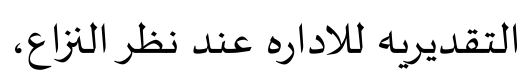

ولا يكفي لحماية المكلفين من تعسف الاداره الضريبيه وجود نصوص قانونيه تنظم الضرائب و فرضها و تحصيلها ، فالقانون بحاجه الى قضاء يراقب حسن تطبيقها و ان يكون القضاء هو تونه

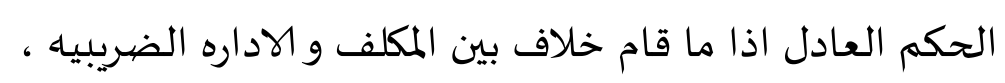

ان دور القاضي في بعض الدول يبحث عما اذا كان تطبيق القانون الضريبي قد طبق تطبيقا

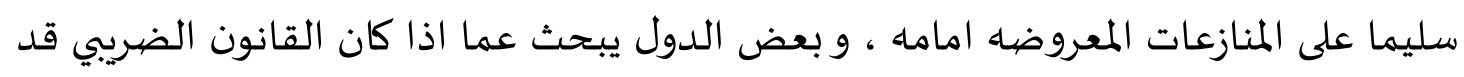

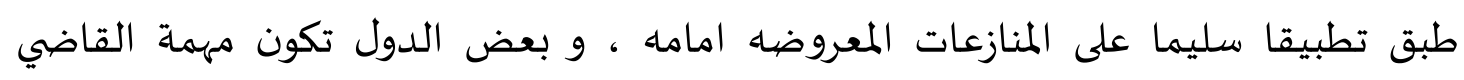
الضريبي الغاء و تعديل التقدير ، فالقضاء الضريبي يعلو قضاء المشروعياه ، 
مجلة العلوم القانونية / كلية القانون - جامعة بغداد العدد الخاص الثالث- الجزء الثاني /

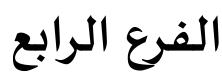

\section{اهمية القضياء الضريبي في اكمال النقص التشريعي}

ان القانون المكتوب هو نتائج ارادة انسان و من ثم فان خلقه كشأن اي فعل انساني عملا

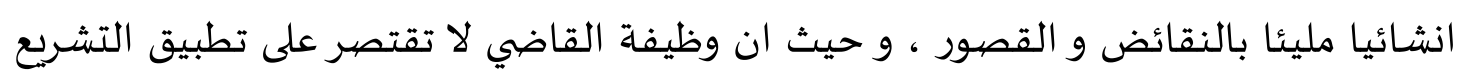

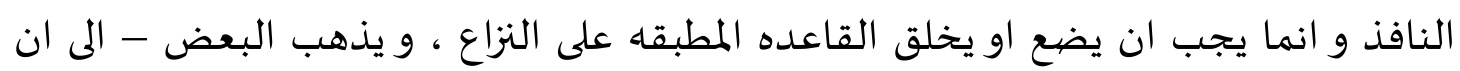

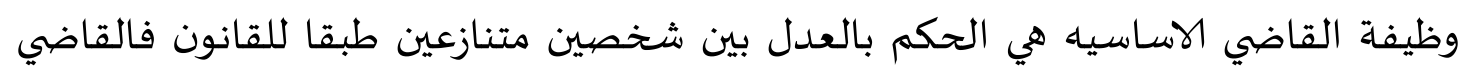

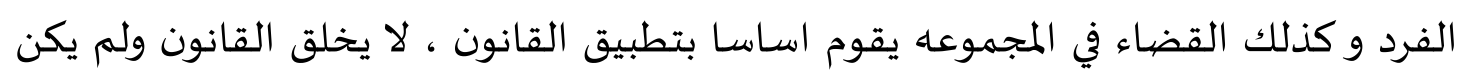

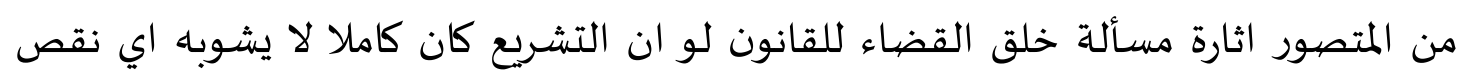

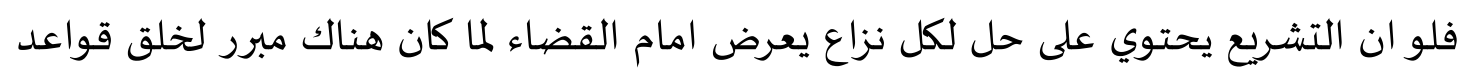

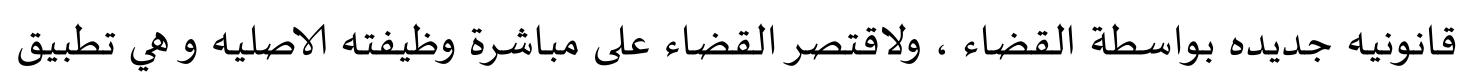

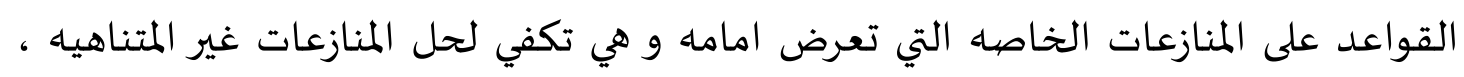
كما في العراق يكون القضاء مصدر تفسيري و احكام المحاكم و ما تستقر عليه غير ملزمه

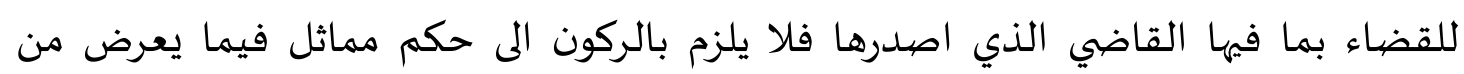
نزاعات مشابها في المستقبل كما في باقي القوانين ، و مع ذلك تنظر لاحكام محكمة التمييز

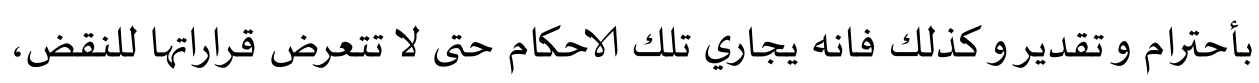

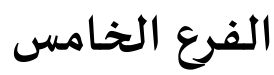

\section{دور القضاء الضريبي في تحقيق الطمأنينة لدى المكلفين الطاعنين}

هدف القضاء بصوره عامه هو تحقيق العداله بين اطراف النزاع ، و يصبح هذا الهدف مطلبا اكبر عندما يكون اطراف الدعوى متكافئين و وضمانا لحقوق المكلفين ، فهو يحقق الحمايه للمكلف من تعسف الاداره الضريبيه في قراراتها او خطاء الاداره اثناء تطبيق القانون ،

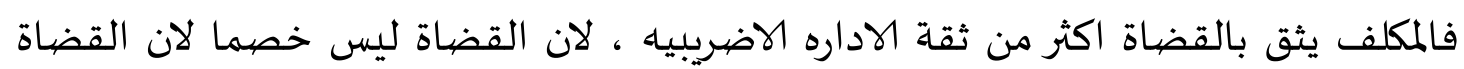

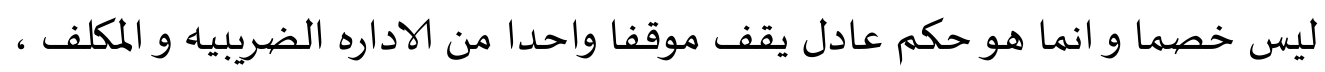


مجلة العلوم القانونية / كلية القانون - جامعة بغداد العدد الخاص الثالث- الجزع الثاني / $r+1 \mathrm{~V}$

ان القضاء من انجح الوسائل لفض النزاعات سواء المرفوعه من قبل الافراد او السلطه

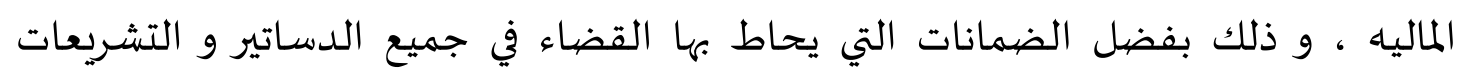
المختلفه و منها التشريع العراقي و التشريع المقارن

و يعتبر الطعن القضائي هو من انجح الضمانات للمكلفين ، و تتبع اهمية القضاء بصوره

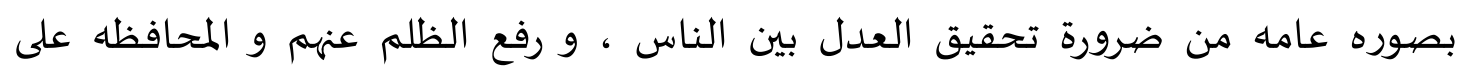
حقوقهم و حرياتهم التي ضمنها لهم الشرائع السماوياه و الدساتيرو النظم القانونيه ، و بذلك تتجلى وظيفة القضاء بأسمى صورها و القضاء صنوان واحد

\section{الفرع السادس}

\section{دور القضياء الضريبي في ضمان الحريه الماليه}

ان الحاجه الى وجود قضياء تشتد في الميدان الضريبي ذلك ان الضريبه تعد قيد على مبداء

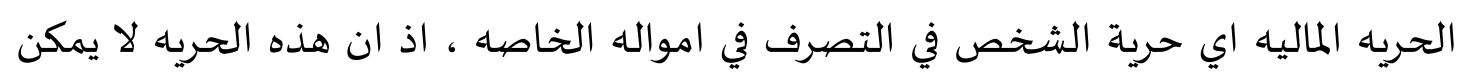
ان تمارس بصوره مطلقه و ذلك بسبب ما تقرره احكام القانون الضريبي من التزام على عاتق

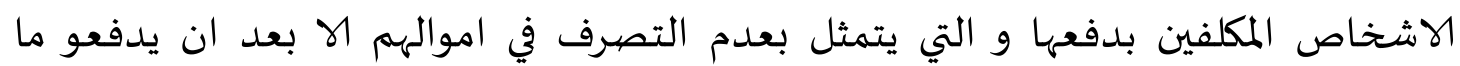
استحق عليهم من ضريباه للدوله ، و ان المباديء الدستوريه التي تضمنتها الدساتير المختلفه

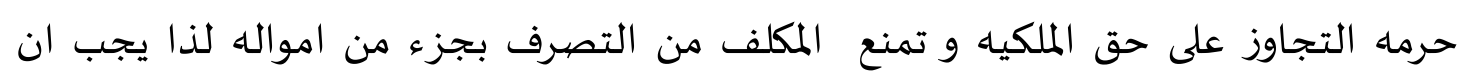

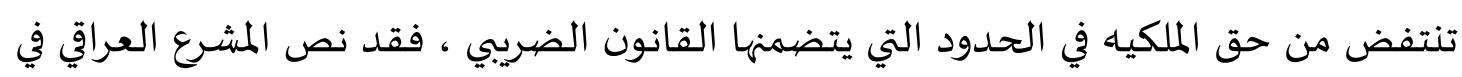

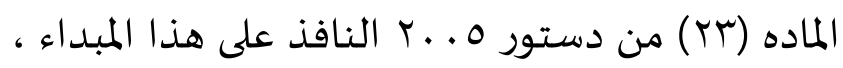
الفرع السابع - عمل القضاء الضريبي في تأصيل مبداء القانون الضريبي ان موضوع الضرائب يعتبر حديثا نوعا ما ، و قواعده ليست مقننه في قانون واحد و خصيوصا ما يتعلق بقوانين الاجراءات ، كما ان النصوص الضريبيه غالبا ما تمتاز بالغموض و و الاههام و 
مجلة العلوم القانونية / كلية القانون - جامعة بغداد العدد الخاص الثالث- الجزء الثاني / $r . I V$

تحتاج الى تفسير ، وان الكثير من المباديء القانونيه في موضوع الضرائب تم ترسيخها بناء على

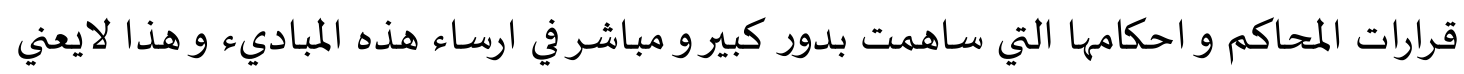
ان هذه الاحكام كانت منسجماه في جميع قراراتها بل العكس هو لكثرة التعديل ،

ان مباديء القانون الضريبي لايتضمنها مجموعاه تشريعيه واحده كما هو الحال بالنسبه

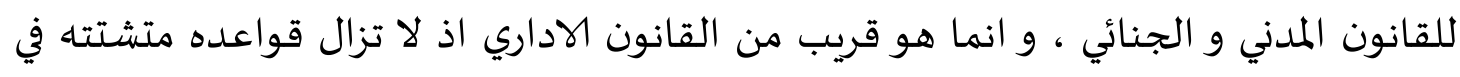

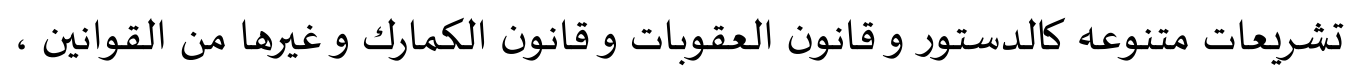

ان مباديء القانون الضريبي لا يتضمنها مجموعاه تشريعيه واحده كما هو الحال بالنسبه كما

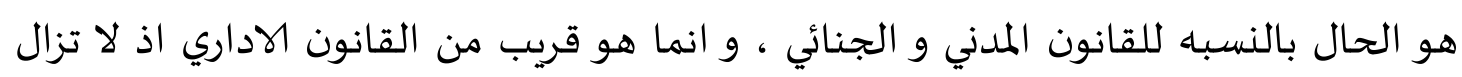
قواعده متشتته في تشريعات متنوعه كالدستور و قانون العقوبات و قانون الكمارك و غيرها من القوانين

الفرع الثامن - دور القضاء الضريبي في تحقيق التوازن بين مصالح المكلفين و الاداره الضريبية

ان الضرائب تقتقطع جزاء كبيرا من اموال المكلفين ، هذه الاموال التي من واجب الدوله حمايتها لا الاجحاف في الاقتطاع منها دون وجه حق و ينبوع من المبالغه ، و تشكل الدوله الطرف الاقوى في العلاقه الضريبيه في مالها من سلطه و سياده على الافراد مستمده من سلطة الدوله نفسها و يجب ان تتمتع ايضا بالحمايه القضائيه الفعاله ، و الفرد طرف فئه

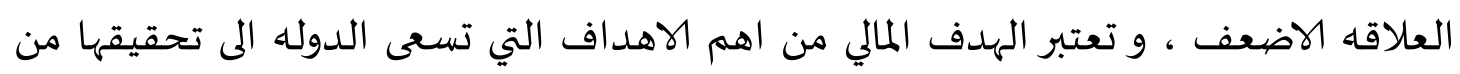
وراء تشريع القوانين الضريبيه بصوره خاصها و الماليه بصوره عامه ، و تحقيق الايرادات للخزينه العامهاء

ان اطراف المنازعه الضريبيه هما المكلف و الاداره الضريبيه ، و هما يمثلان مصلحتين متباينتين ، حيث ان مصلحة المكلف هي فرديه او شخصيه ، في حين ان مصلحة الاداره هي

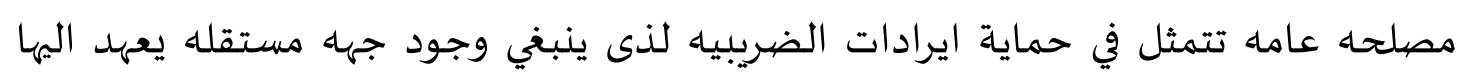
مهمة الفصل في التعارض و توفير حمايه الاطراف العلاقه الضريبيه 
مجلة العلوم القانونية / كلية القانون - جامعة بغداد العدد الخاص الثالث- الجزء الثاني / $r+1 \mathrm{~V}$

و ان تحقيق التوازن بين هاتين المصلحتين المتعارضتين يوفر الحمايه للمكلف و ايضا يرفد

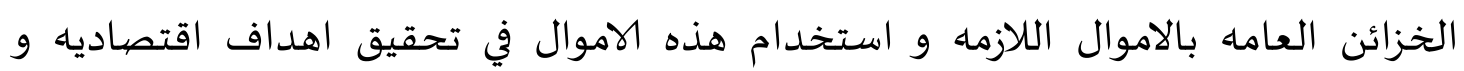

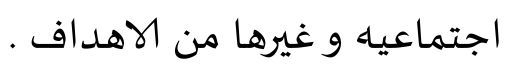

\section{المطلب الثالث}

\section{الملامح الاسـاسيه للقضاء الضريبي}

ان القانون الضريبي يبقى محتفظا باستقلاليه و ذاتيه خاصها بسبب ان التطور الذي يصيبه يختلف عن التطور الذي يصيب غيره من فروع القانون ، و ينظر القانوالضريبي في المكلف

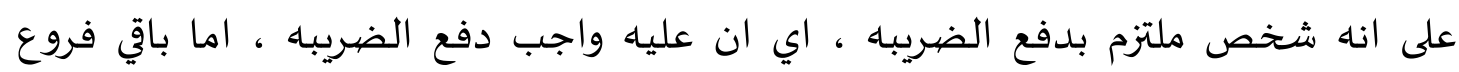
القانون فيتم النظلر له على انه مواطن مما يعيني ان اختلاف مركز الفرد كمكلف عن مركزه

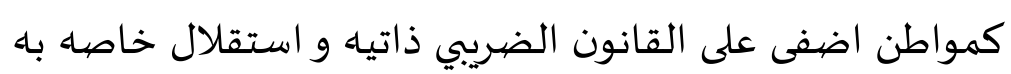
و على الرغم من التقارب الجلي بين القضاء الضريبي و القضاء الاداري في بعض المعالم الا انه يوجد تباين واضح في معالم اخرى مما يستوجب من القاضي الضريبي مراعاتها ، لذلك فأن

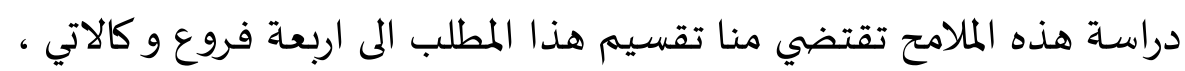

$$
\text { الفرع الاول - طبيعة المنازعات الضريبيه }
$$$$
\text { الفرع الثاني - نوع المنازعات الضريبيه }
$$

الفرع الثالث - سربة جلسات المنازعات الضريبيه

الفرع الرابع سرعة الفصل في المنازاعات الضريبيه 
مجلة العلوم القانونية / كلية القانون - جامعة بغداد العدد الخاص الثالث- الجزء الثاني / $r+1 V$

\section{الفرع الاول}

\section{طبيعة المنازعات الضرببيه}

هناك تعريفات عديده للمنازعات الضريبيه ، نذكر منها بانها :- نزاع يقوم بين السلطه الماليه بوصفها اصدرت قرارا اداريا بالتكليف بدفع مبلغ الضريبه و يمثلها دائرة الضريبه ، الطرف بهرة الثاني هو المكلف بدفع الضريبه فلا تقبل الدعوى الا من مكلف تحققت الضريبه بحقه ، كما عرفت على انها الخلاف الذي يثور بين الاداره الضريبيه و المكلف بمناسبة قيامها بوظائفها التي كفلها لها قانون الضريبه او اي قانون اخر ، و كان للكتاب و الباحثين وجهات نظر بهر التراره مختلفه حول هذه الطبيعه

بعض الكتاب يعتبر المنازعه الضريبيه ذات طبيعه اداريه ، لان احد اطرافها جهة الاداره و بالتالي نادوا بتطبيق لقانون الاداري عليها ، فربط الضرائب غالبا ما يكون بقرار اداري و سلطات الاداريه في مزاولتها لنشاطها و افصاحها عن ارادته الملزماه ، انما تصدر من جانبها وحدها قرارا اداريا في المجال الضريبي ، لانها تثور في الاساس ضد قرار صنار صادر من الاداره الضريبيه التي تمثل السلطه التنفيذيه في عملية فرض الضريبه و جبايتها و لما تتمتع باه الاداره من سلطات و امتيازات تفوق تلك التي تتمتع باه غيرها من الجهات الاداريه مع ملاحظة ان بعض الفقهاء يذهب للقول الى ان القضاء الضريبي ينتمي للقضاء الاداري

فيما يرى البعض الاخر منهم ان المنازعات الضريبيه ذات طبيعاه ليست اداريه التي انفرد بهذا الرأي (دكتور مصطفى كمال) ، و يجب تطبيق القانون المدني عليها بمقوله ان القانون المدني

$$
\text { هو الشريعه العامه لشتى فروع القانون الوضعي }
$$

بينما الفريق الثالث من الكتاب و الباحثين يرى بان المنازعه الضريبيا ذات طبيعه خاصها و نؤيدهم الرأي ، استنادا لذاتية القانون الضريبي نفسـا لئه 
مجلة العلوم القانونية / كلية القانون - جامعة بغداد العدد الخاص الثالث- الجزء الثاني /

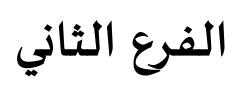

\section{نوع المنازعات الضريبية}

تعرف الخصومه لغة بانها :- الجدل بالضم الجدل خاصمه خصاما و مخاصمه فخصيمه

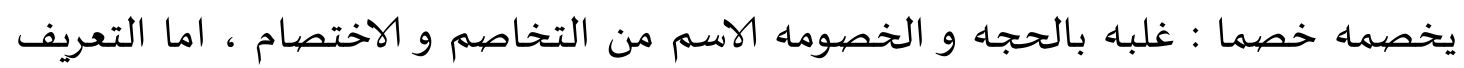
الاصطلاحي للخصوم هتاتي بالضم الجدل حيث تمثل مجموعه من الاعمال الاجرائيه و

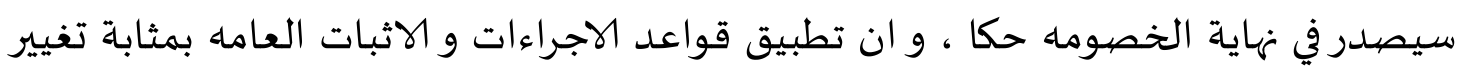
في طبيعة المنازعات الضريبيه

اولا الخصومه الضريبيه ذات طبيعاه موضوعياه

تشير الخصومه الموضوعيه الى وقوع اعتداء على مركز قانوني عام من خلال قرار معيب

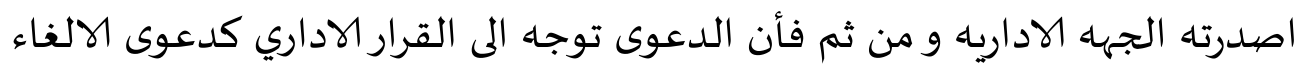

و تختلف المنازعات الضريبيه عن غيرها من المنازعات من حيث طبيعة اطراف هذه المنازعات الضريبيه ، باعتبار ان احد اطرافها هي الدوله و ان طبيعة المنازعات الضريبياه موضوعياه مردها الى قاعدة الشرعيه و مبداء سيادة القانون ، و متطابقه مع طبيعة المنازعات الاداريه التي يستقل بنظرها القرار الاداري ، و لكون قرارات تقدير لضريبه ماهي الا قرارات اداريه و ان الطعن فهها يتم من خلال وسيلة حماية مبداء الشرعيه المتمثله بالقضاء الاداري اي انها تكون ضد قرارات الاداره الضريبياه و هذه الخصوماه تمس اموال المكلفين

ويرى الباحث ان طبيعة المنازعات الضريبيه موضوعيه ، بالاستناد الى ان المكلف يكون في مركز موضوعي تجاه الاداره الماليه ، و ليست ذات طبيعه شخصيه ، التي يكون بها المكلف بمركز شخصي فياه علاقه المدين بالدائن ثانيا :- المنازعات الضريبيه ذات طبيعه شخصيه 
مجلة العلوم القانونية / كلية القانون - جامعة بغداد العدد الخاص الثالث- الجزء الثاني /

في حال ادعاء شخص يقدم للقاضي يدعي فيه بوقوع اعتداء على حق خاص له او على الاقل تهديد باعتداء على هذا الحق فتظهر الخصومة بين شخصين ادعاء الدائن بحقه من قبل

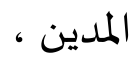

$$
\text { ثالثا :- المنازعات الضريبية ذات قانونياه مستقله }
$$

ان المشرع الضريبي في العراق قد اعطى المنازعات الضريبيه طبيعاه قانونيه مستقله ، مستمده من المباديء التي يقوم عليها القانون الضريبي و استقلاليته لما له من ذاتيه كامله ، و و تتلاقى في المنازعات الضريبيه ذات طبيعاه مختلطه عناصر الخصومه الشخصياء مع عناصر الخصومه الموضعيه فيدور جانب منها حول المشروعيه قرار فرض الضريبه او حول صحة تقدير الايرادات الخاضعه لها ، و يدور من جانب اخر حول استرداد المبالغ التي دفعها المكلف زياده عما هو مستحق عليه قانونا و غيرها من المنازعات مما يبرز في بعضها العناصر الشخصيه للخصومهاه

يرى (د. علي هادي الهلالي) و نؤيده الرأي في ان المنازعات الضريبيه ذات سمه موضوعياه تمتزج بعنصر اخر ال وهو الطبيعاه الفنيه و قد تكون الطبيعه الفنيه طاغيه على الطبيعاه الموضوعيا ، مما يتطلب خبرات قضائيه ممتزجه بخبرات متخصصه بأسباب المنازعات الضريبيه و طبيعتها و نتائجها على المكلف و الخزانه العامه على حد سواء ،

\section{الفرع الثالث}

\section{سرية الجلسات}

السرية من السمات الاساسية لاجراءات التقاضي الضريبي ، فالاصل كقاعدة دستورية ان تتم المحاكمة او المرافعة علنية الا اذا رات المحكمة ان تكون سرية مراعاة للنظام العام او محافظة على الاداب العامة ، كما في نص الفقرة (سابعا ) من المادة 19 من الدستور العراقي النافذ على ان ( جلسات المحاكم علنية الا اذا قررت المحكمة جعلها سرية ) ، واكد قانون 
مجلة العلوم القانونية / كلية القانون - جامعة بغداد العدد الخاص الثالث- الجزء الثاني / r. IV

التنظيم القضائي بالرقم .17 لسنة 19V9 المعدل في المادة (0) منه على ان جلسات المحاكم

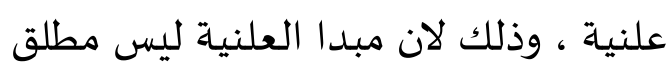

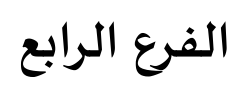

\section{سرعة الفصل في المنازعات الضريبية}

تتجة معظم التشريعات الضريبية الى اعطاء المكلف فرصة تقدم اعتراض على القرار التقدير

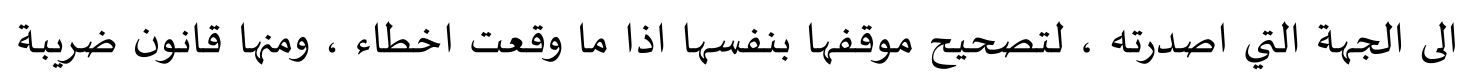

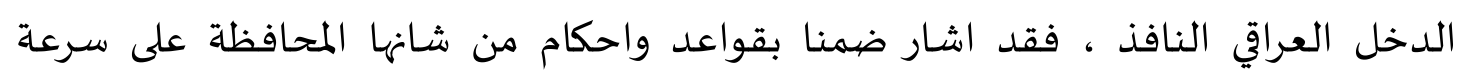
الفصل في المنازعات الضريبية واحاطتها بنوع من السرية للمحافظة على سمعة المكلف امام

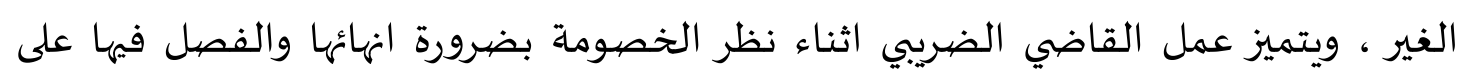
وجه السرعه وتجنب الشكليات وطول الاجراءات وتعقيدها لضمان تحقيق استقرار في الاوضاع للمكلفين في اسرع وقت من جهة ، ورعاية مصالح الخزانة العامة من جهة اخرى ، ولكن مع هذا يجوز التاخير لاسباب معقولة .

\section{المطلب الاول}

\section{القضاء الضريبي في التشريع المقارن}

اختلفت التشريعات المقارنة بشان تحديد الجها التي تتولى نظر الماعزعات الضريبية وتحديد طبيعة القرار الصادر عن جهات الطعن الضريبي لذا سوف نشير الى ذلك من خلال الفرعين

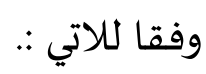

الفرع الاول : تحديد الجهاة صاحبة الاختصاص في نظر المنازعات الضريبية الفرع الثاني : تحديد طبيعة القرارات الصادرة عن جهات الطعن الضريبي 
مجلة العلوم القانونية / كلية القانون - جامعة بغداد العدد الخاص الثالث- الجزء الثاني / $r+1 V$

\section{الفرع الاول}

\section{تحديد الجهة صاحبة الاختصاص في نظر المنازعات الضرببية}

اجمعت الكثير من تشريعات ضريبة الدخل على حق المكلف بسلوك طرق الطعن القضائي اذا لحقه اجحاف وضرر ، بالاستناد الى الحق الاصلي الذي كفلته دساتير الدول كافه ، فمن

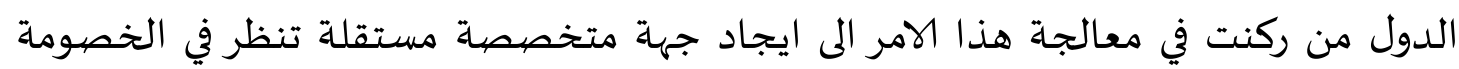

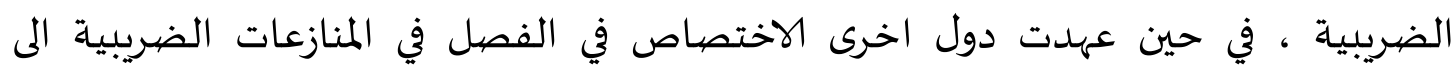
القضاء العادي على ان يتم التقاضي على ثلاث درجات يعبر عنه بالطرق العادية ( البدائية والاستئناف والتمييز) وان دولا ثالثة اجازت للقضاء الاداري فحص الخصومات الضريبية ن وقد استحدثت بعض الدول جهازا قضائيا مستقلا عن كل من القضائين العادي والاداري ، ، لذا سنتناول بيان هذه الجهات ومدى حماية التي يتمتع بها المكلف الضريبي في كل نظام من الانظمة من خلال هذا التقسيم الاتي : لدان اولا انظمة تجعل الاختصاص للقضاء العادي ثانيا : انظمة تعقد الاختصاص للقضاء الاداري ثالثا : انظمة تجعل الاختصاص مشتركا بين القضائيين العادي والاداري رابعا :انظمة تعقد الاختصاص لقضاة متخصصيون الفرع الثاني

تحديد طبيعة القرارات الصيادرة عن جهات الطعن الضريبي

لقد تضاربت الراء حول الطبيعة القانونية للقرارات الصادرة عن جهات الطعن الضريبي فيما اذا كانت قرارات ادارية ام قضائية ، لذا سنتناول ذلك في بحث هذا الموضوع كالاتي :

$$
\text { اولا : قرارات جهات الطعن الضريبي هي قرارات ادارية }
$$


مجلة العلوم القانونية / كلية القانون - جامعة بغداد العدد الخاص الثالث- الجزء الثاني / $r+1 \mathrm{~V}$

$$
\text { ثانيا قرارات جهات الطعن الضريبي هي قرارات قضائية }
$$

اتجه بعض الكتاب والباحثين الى المعايير ذات الصبغة الشكلية ، بينما اتجه اخرين الى المعايير المادية لحل مشكلة التمييز بين القرارات التي تصدر عن جهات الطعن وتعتبر قرارات ادارية وفقا للاتي :

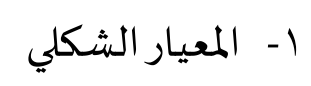

يستند هذا المعيار الى مبدا الفصل بين السلطات ، ويرجع في تحديد العمل الى مركز القائم

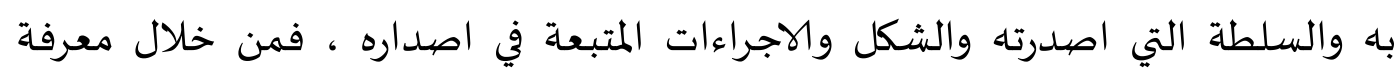
الجهة مصدره العمل القانوني نصل الى معرفة التكييف القانوني للعمل .

فقد ذهب بعض الكتاب والباحثين الى اعتبار قرارات جهات الطعن الضريبي هي قرارات

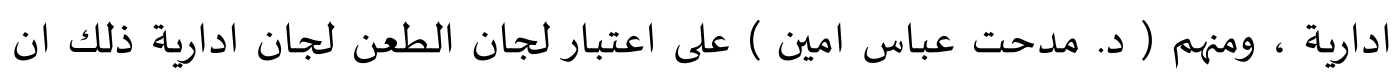
رئيسها لايمكن اعتباره محايدا ، وان اللجنةغير مقيده بالقواعد الشكلية الواردة في القانون المرافعات ، لذا ينطبق هذا الوصف الاداري على القرار الصادر عنها اذا كان رئيس اللجنة موظفا حكوميا محسوبا على جهة التنفيذ لا القضاء.

اضافة الى ان اعضاء السلطة المالية هم موظفيين عموميين في دائرة الضريبة الدخل مخولين باصدار قرارات ادارية ، وما يدره من اعمال تؤثر على المراكز القانونية للمكلفين وان جميع من خلعوا الطبيعة الادارية البحته عن جهات الطعن الضريبي هم من المؤييدين لاعتبار القرارات صادرة جهات الطعن الضريبي قرارات ادارية .

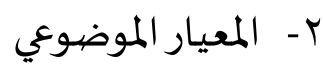
ان من الكتاب والباحثين من ذهب الى الاخذ بمعيار عندما نظر الى قرار السلطة الادارية لايحمل اساسا قاعدة قانونية خصومة او منازعه حول مركز قانوني المقصيود منه احداث 
مجلة العلوم القانونية / كلية القانون - جامعة بغداد العدد الخاص الثالث- الجزء الثاني / r. IV

اثر في المراكز القانونية انشاء او تعديل او الغاء وبالتالي فهو ليس قرارا قضائيا وينقل

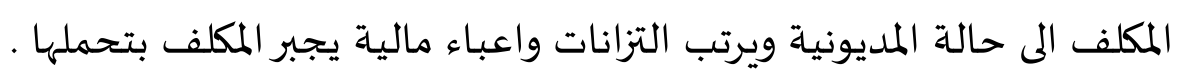

فاذا كانت عضوية احد القضاة او رئاسة لهذا اللجان الإدارية امرا نظريا ، وواقعيا في

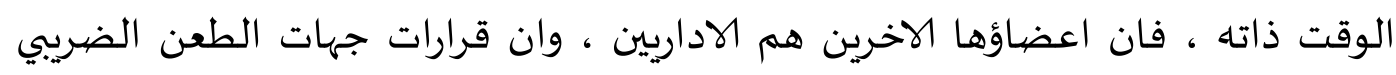
ذات طبيعة ادارية المحدد لدين الضريبة موضوع الطعن . ثانيا قرارات جهات الطعن الضريبي هي قرارات قضائية ذهب جانب من الكتاب والباحثين بصدد القرارت الصادرة من جهات الطعن الضريبي على انها قرارات قضائية متكئين على بعض عناصر المعيار الموضوعي والمعيار المختلط وهي كلاتي :

$$
\text { 1- المعيار الموضوعي }
$$

يقوم على اساس جوهر العمل القضائي بان يتمتع ذلك العمل بحجية الشيء المقضي بها

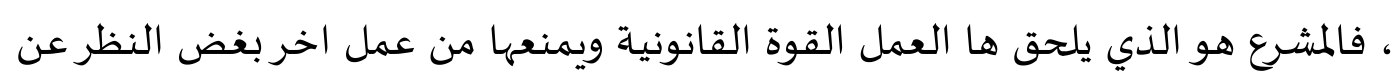

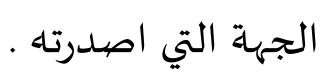

ان القرارات الصادرة عن لجان الطعن بمثابة احكام قضائية صادر عن محكمة ادارية ووقفقا لهذا الراي فان لجان الطعن تعتبر محاكم ادارية ويعتبر كل من المكلف والسلطة المالية

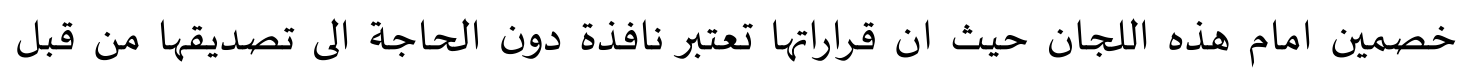
دائرة الضريبة ووزارة المالية .

وان هذا الاتجاه يركز على المعيار المادي المرتبط بطبيعة عمل هذه الجهات حيث ينظر الى

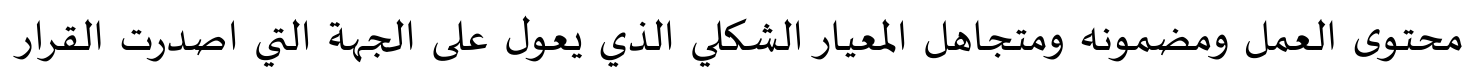
وان القرارات التي تصدر عن جهات الطعن هي قرارات قضيائية

r- المعيار المختلط 
مجلة العلوم القانونية / كلية القانون - جامعة بغداد العدد الخاص الثالث- الجزء الثاني /

ان هذا المعيار يجمع بين عناصر المعيارين الموضوعي والشكلي ، بالاعتماد على معيار خاص

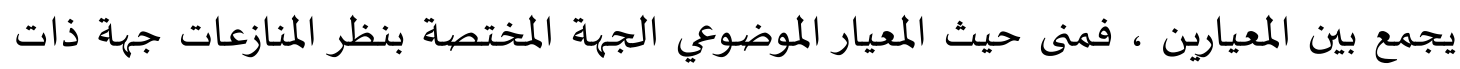

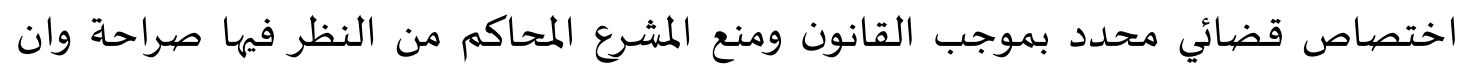

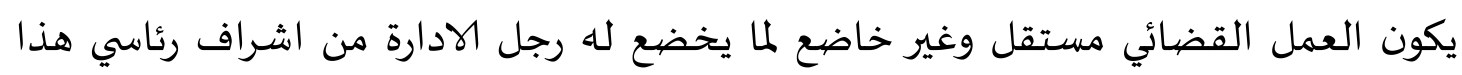

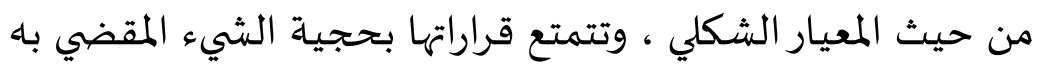

ان قرارات لجان الطعن الضريبي في العراق ذات اختصاص قضائي لما تتمتع تلك القرارات بها من حجية الشيء المقضي بهاه وان لم يشر اليه المشرع بصورة صريحة الاوان ذلك الامر مستفاد

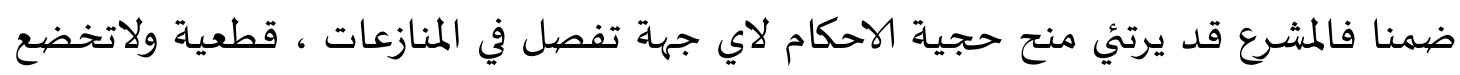

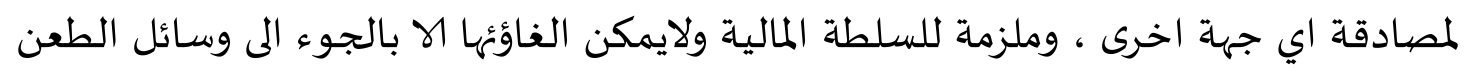

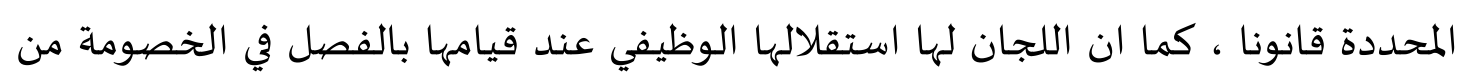

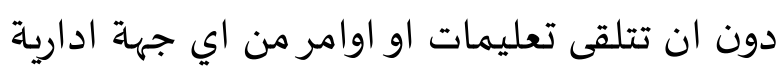
المطلب الثاني

\section{مراحل الطعن القضائي في العراقي}

يذهب المشرع العراقي نحو اتجاه مختلف عن التشريعات المقارنة ويتمثل هذا الاتجاه باناطة الرقابة على اعمال الادارة الضريبية والطعن في قراراتها الى جهات مختلطة بين القضياء والادارة ، وهذا هم مسلك المشرع العراقي في كل القوانين الضريبية التي صدرت ولغاية ان فيما يعرف بلجان الطعن الضريبي ، واحاطه بعض الاجراءات الخاصة عند نظر الدعوى الضريبية حيث اشترط قانون ضريبة الدخل النافذ على المكلف سلوك طرق الطعن الاداري قبل اللجوء للطعن القضيائي .

وغالبا ماتدخل تشريعات الادارة الضريبية طرف مقابل في المنازعة الضريبية ، من ضمن

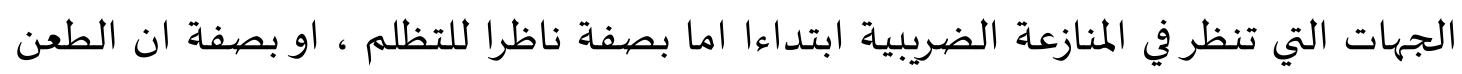

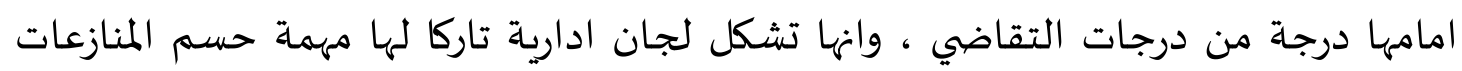


مجلة العلوم القانونية / كلية القانون - جامعة بغداد العدد الخاص الثالث- الجزء الثاني /

الضريبية المثارة بعد ان فرض على المكلف الاعتراض على قرار الادارة المالية المرتبط بالدخل

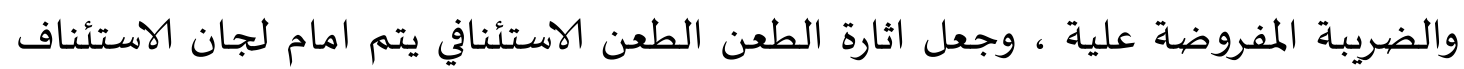

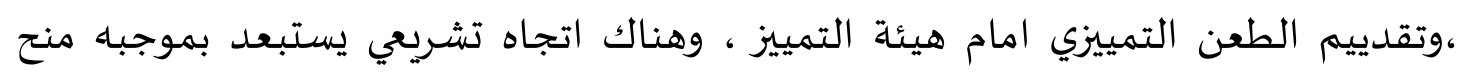

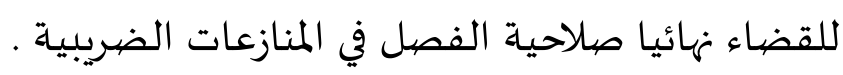
حدد المشرع العراقي للمكلف ثلاث مراحل ثلاث متسلسة للطعن ، واجب عليه المضي بها تباعا لذا سنقسم هذا المطلب وفقا للفروع الثلاث كالاتي : الفرع الاول : الاعتراض على التقدير امام الجهة الادارية الفرع الثاني : اللجان الاستئنافية الفرع الثالث : الهيئة التمييزية

\section{الفرع الاول}

\section{الاعتراض على التقدير امام الجهة الادارية}

في العراق يشترط المشرع ان يسبق الطعن امام القضاء الاعتراض على التقدير امام الجهاة الادارية ، حيث يباشر المكلف اعتراض امام الادارة الضريبية التي اصدرت القرار المطعون والتي

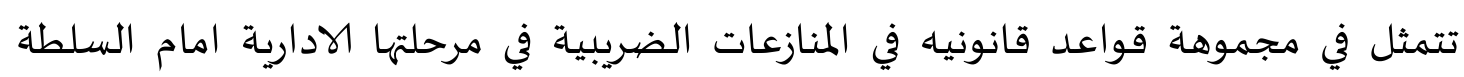

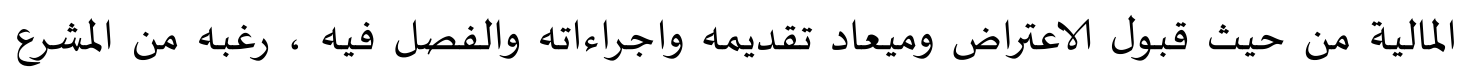

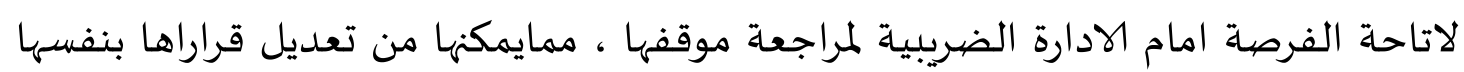

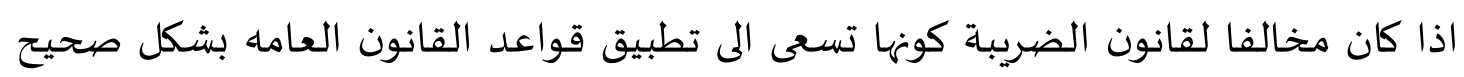
وتستهدف الصالح العام . مان.

ان المشرع الضريبي العراقي وضع حكما خاصا بالاعتراض على القرارات موظفي الادارة المالية ووضع لها ضوابط خاصة تختلف بعض الشي عن ضوابط والاحكام الواجب اتباعها في التظلم الاداري بشكل عام فمثلا لم يجز الاعتراض على قرار التقدير الا بعد التبلغ به بينما 
مجلة العلوم القانونية / كلية القانون - جامعة بغداد العدد الخاص الثالث- الجزء الثاني / r.IV

يجوز التظلم الاداري الاعتيادي بمجرد العلم به حتى قبل التبلغ به وايضيا من حيث المدة

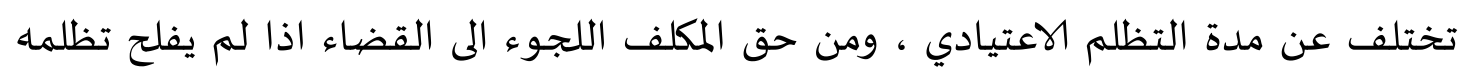
امام اللسطة المالية ، حيث انها من قمة الضمانات التي يمكن للمكلف الحصول عليها ، وعليه سنتناول موضوع التظلم وفقا للاتي : اولا : شروط الاعتراض على التقدير امام الحهة الادارية ثانيا : اثار الاعتراض على التقدير امام الجهة الادارية اولا : شروط الاعتراض على التقدير امام الجهة الادارية

ان المشرع العراقي في قانون ضريبة الدخل اجاز للمكلف ان ينازع في صحة تقدير الدخل وفرض الضريبة عليه بالاعتراض امام الادارة المالية الصادربهذا الشان امام نفس الموظف الذي اصددر القرار المراد الاعتراض عليه ، وذلم بالاعتراض ( التظلم ) كتابه الى دائرة الضريبة التي بلغته او الى الهيئاة العامة للضرائب خلال مدة واحد وعشرين يوما من تاريخ تبليغه

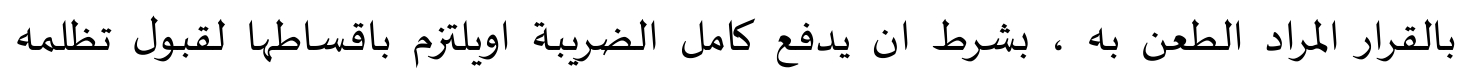
،لذلك لابد من توافر عدة شروط في التظلم الوجوبي المقدم من قبل المكلف امام الجهاة الادارية نورده وفقا للاتي : ا - ان يقدم المكلف طلب الاعتراض على قرار التقدير تحريريا للسلطة المالية وخلال المده

$$
\begin{aligned}
& \text { القانونية . } \\
& \text { r- وجوب دفع المكلف مبلغ الضريبة ( مبدا الدفع ثم الاسترداد ) : } \\
& \text { ثانيا :. اثار الاعتراض على التقدير امام الجهة الادارية }
\end{aligned}
$$

اذا اعترض المكلف على قرار السلطة المالية بتقدير الدخل وفرض الضريبة ، فانه امام

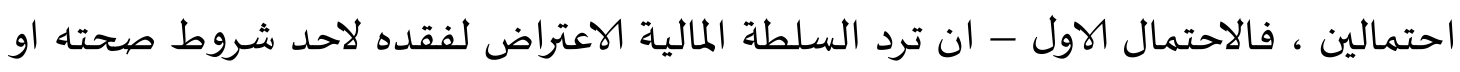

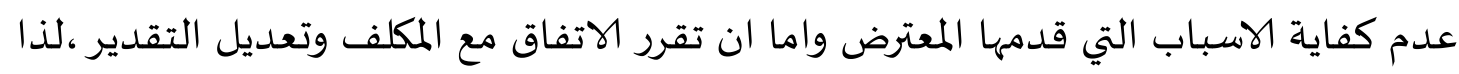
سنبحث الموضوع بنقطتين كالاتي : 
مجلة العلوم القانونية / كلية القانون - جامعة بغداد العدد الخاص الثالث- الجزء الثاني /

\section{ا - رد السلطة المالية الاعتراض المقدم من قبل المعترض r- الاتفاق بين السلطة المالية والمعترض}

1- - رد السلطة المالية الاعتراض المقدم من قبل المعترض

ان السلطة المالية ترفض الاعتراض المكلف على تقدير ، فاللمكلف ان يستانف قرار السلطة

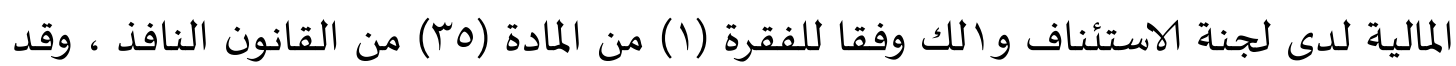
ايدت اللجان الاستئنافية والهيئة التمييزية هذا الاتجاه بالكثير من قراراتها على انه ( اذا اجرت السلطة المالية التقدير ، فالمكلف اما ان يقبله او ان يعترض عليه امام مراجع الطعن ) كما ان السلطة المالية ان ترد الظلم وتصر على صحة الاجراءات وقراراتها المتخذه ،وذلك عندما ترفض الاعتراض على التقدير المقدم من قبل المكلف اذا قدم المكلف خارج المده ، لما لها من اختصاص واسع التقدير ، فهذا الامر جوازي متروك للسلطة المالية . r- الاتفاق بين السلطة المالية والمعترض

ان من نتائج التظلم او الاعتراض فان السلطة المالية قد تلغي قرارها المطعون او تعدله وتعرض التعديل على المكلف ، الذي قد يوافق على التعديل او لايوافق ، ولك بعد ان يتبين للسلطة المالية توافر جميع شروط صحة الاعتراض من الناحية الشكلية وان المكلف دفع

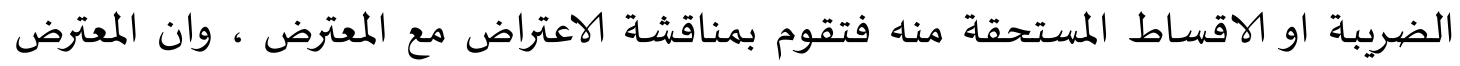
محق في اعتراضيا فتقوم بتعديل التقدير بالاتفاق مع المكلف باخذ توقيعاه على التقدير المتفق بينهما وبدون التوقيع لايوجد اتفاق ، لان التوقيع على المحرر الرسمي لايقبل الطعن به باي طريق الا بالتزوير ، حيث يترتب على التوقيع صيرورة التوقيع قطعيا .

ويمكن للسلطة المالية ان تقوم بتدارك اخطاء محاسبية او قانونية شابت الاجراءات فرض الضريبة بزيادة مبلغ الضريبة او فرض مبلغ اضافي او غرامه او اي اجراء يجعل المكلف

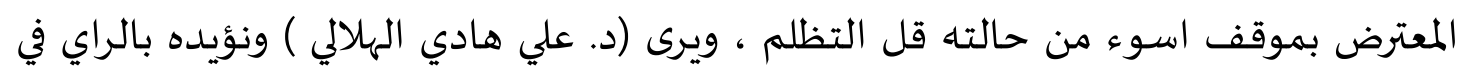
ان على الرغم من ان المشرع الضريبي العرالقي يحرص على تدعيم المركز القانوني للمكلف من 
مجلة العلوم القانونية / كلية القانون - جامعة بغداد العدد الخاص الثالث- الجزء الثاني / r.IV

خلال ضمان الحقوق والضمانات في التقاضي وتقديم الطعون الضريبية الا ان المشرع الضريبي المصري يوفر ضمانه قضائية اوسع ، فبعد ان كفل مرحلة الاعتراض ، ومرحلة

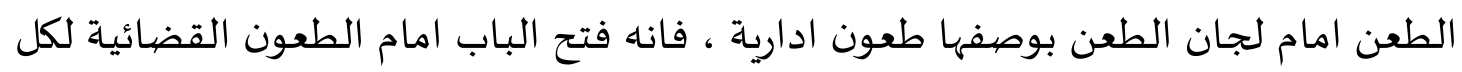

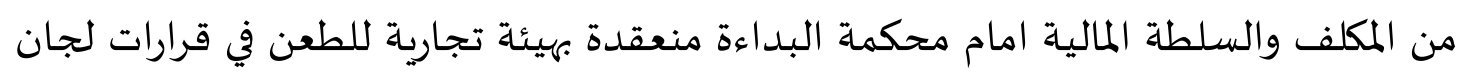
الطعن ، كما يمكن للطعن استئنافا بالقرار القضائي الذي تصددره المحكمة البدائية .

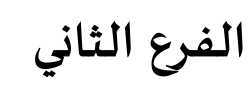

\section{اللجان الاستئنافية}

اجاز قانون ضريبة الدخل النافذ للمكلف التي رفضت السلطة المالية اعتراضها بشان تقدير وفرض الضريبة ان يستأنف قرارها لدى الجهة المختصة التي تنظر فيه .

ان لجنة الاستئناف هي عبارة عن لجنة ادارية ذات اختصاص قضائي ، وعليه فالسلطات التي

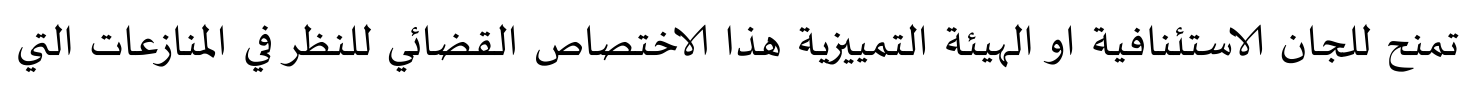

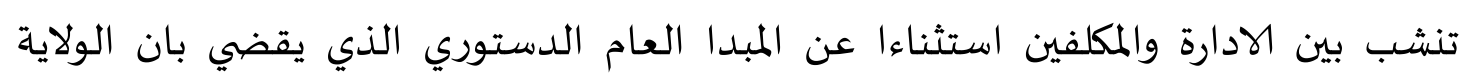

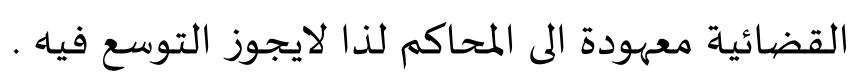
وعليه سنتناول الاعتراض امام اللجان الاستئنافية وفقا للاتي :. اولا : شروط طلب الاستئناف ثانيا : اثار طلب الاستئناف

اولا : شروط طلب الاستئناف اشترط المشرع الضريبي العراقي لقبول الاستئناف والنظر فيه من قبل لجان الاستئناف توافر عدة شروط هي : 
مجلة العلوم القانونية / كلية القانون - جامعة بغداد العدد الخاص الثالث- الجزء الثاني / r.IV

1- ان يقدم المستانف طلب الاستئناف تحريريا وخلال المدة القانونية

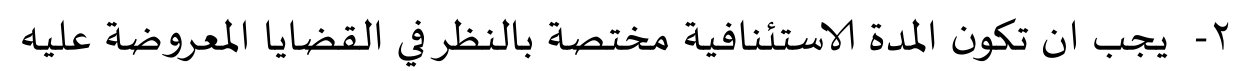
ثانيا : اثار طلب الاستئناف

حددت المادة (דr) ن قانون ضريبة الدخل رقم r/1 لسنة r191ا النافذ وظيفة لجان الاستئناف بالفصل بالخصومة المعروضة بالغاء تقدير الضريبة التي حدده المخمن لدخل

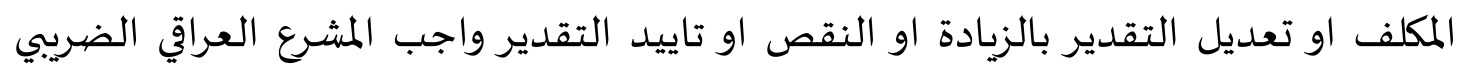
على لجان الاستئناف ان تقوم بتسبيب قراراتها وبخلاف ذلك تكون هذه القرارات عرضها للنقض .

$$
\text { r r- r- الغاء قرار التقدير }
$$

ا- الغاء قرار التقدير :. يترتب على صدور قرار لجنة الاستئناف ان يصبح مقدار الضريبة كما حددته اللجنة واجب الاداء واذا ماقررت لجنة الاستئناف الغاء التقدير واعفاء المستانف من الضريبة ، كان دفع الضريبة كلا او بعضا فان السلطة المالية تقوم بالرد مادفع المستانف عليه وذلك بناءا على طلب منه اذا لم لم تكن الضريبة قد دفعت عن طريق الاستقطاع المباشر فاذا كانت كذلك فلا داع

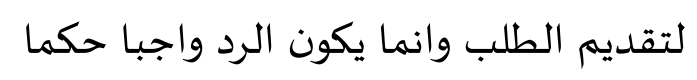

ץ- تاييد قرار التاييد :. يجب التركيز على مااشارت اليه العبارة التالية من المادة (جr) من قانون ضريبة الدخل الى ان (... كما ان لها ان تؤيد التقدير اذا لم يحضر لمريك

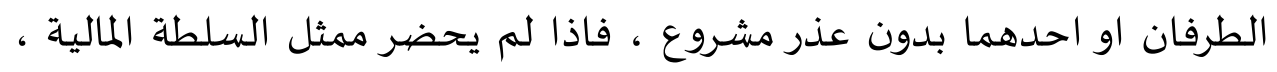
فكيف يؤيد التقدير الذي لك يرضى المكلف به ، لان السلطه المالية قد تلجا 
مجلة العلوم القانونية / كلية القانون - جامعة بغداد العدد الخاص الثالث- الجزء الثاني /

لعدم حضور كلما شات ذلك ، وان من الانسب ان تؤجل اللجنة النظر في الاستئناف لمده مناسبة كما نص عليه المشرع العراقي .

r- تعديل قرار التقدير :. ان اللجنة الهتئنافية في سبيل اصدار قراراها ان تطلع على كافة الاضابير والسجلات والمستندات المتصلة بالموضوع ، ولايقتصر سلطة القاضي على الغاء القرار غير المشروع بل يمتد دور القاضي الى تعديل الضريبة سواء بالزيادة تقدير الضريبة او تخفيضة . .

اناط القانون الضريبي العراقي لجان الاتئناف مهمة البت في كل ماله صله بتقدير الدخل وخضيوعه للضريبة ، حيث اعطى هذه اللجان سلطة واسعها بزيادة التقدير ان قدرت السلطة المالية دخل المكلف اقل مما ينبغي عليها تقديره حفاظا على حقوق الخزانه ، مع ملاحظة القاعدة العامة التي تقضي بان لايضار الطاعن بطعنه واذا اكتملت جميع شروط القبول الاستئناف شكلا وحضر الطرفان في موعد المحدد لنظر الاستئناف ورات اللجنة الاستئنافية ان السلطة المالية قد قدرت دخل المستئانف الاكثر مما ينبغي او انها لم تقم بمنحاه سماحا قانونيا يستحقه فتقوم

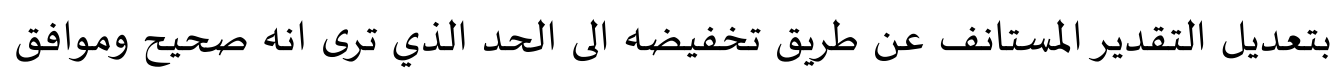
للقانون مبينه اسباب ذلك .

القانون الضريبي بموجب الفقرة (؟) من المادة (9؟) منه خوله لجنة الاستئناف النظر في المخالفات المرتكبه خلافا لنظام مسك الدفاتر ، بفرض غرامه منصوص عليها في

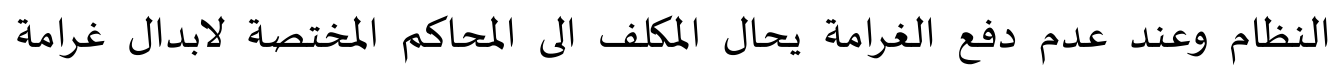
بالحبس ، ان هذا الوضع ينسجم مع حالة الشخص الطبيعي ، واما بالنسبة للشخص المعنوي ( الشركات ) فلا يجوز يحكم عليه بغير الغرامه . 
مجلة العلوم القانونية / كلية القانون - جامعة بغداد العدد الخاص الثالث- الجزء الثاني /

\section{الفرع الثالث}

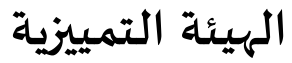

بعد ان تنتهي عملية الاعتراض امام اللجنة الاستئنافية وتصدر قرارها ، تبدا مرحلة الطعن في القرار الاستئنافي امام الهيئة التمييزية وذلك لمنح المكلف الطمانينه وتحصيين قرارات السلطة المالية واللجان الاتئنافية من الخطا وتوفير الحماية القانونية للمكلف الضريبي .

ويلجا طرفا الخصومة معا الى تمييزه احكام وقرارات لجان الاستئناف ، حيث يشكل اخر فرصها للمكلف بالاعتراض على مبلغ الضريبة المقدره عليه من قبل دائرة ضريبة

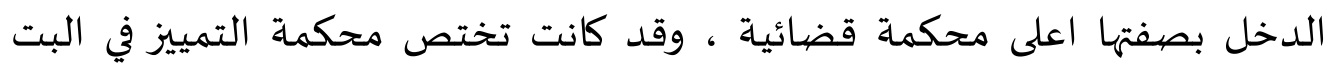
بالنقاط القانونية الواردة في الطلب فقط دون النظرفي الوقائع والمور غير القانونية ، اذا كانت قرارات اللجان التدقيقة القطعية ولغرض التعرف على كل ما يتعلق بالتمييز كطريق طعن اخير بقرارات لجان الاستئناف سنتكلم عن

اولا :. شروط طلب الطعن التمييزي ثانيا :. اثار طلب الطعن التمييزي

اولا :. شروط طلب الطعن التمييزي لابد لقبول التمييز من توافر عدة شروط جاءت بها المادة (.ع) من قانون ضريبة الميرية الدخل النافذ وهذه الشروط هي :

ا- ان يقدم طالب التمييز طلبا تحريريا وخلال المدة القانونية r- يجب ان تكون اللجنة التمييزية مختصية بالنظر في القضايا المعروضاة عليها . ثانيا :. اثار طلب الطعن التمييزي 
مجلة العلوم القانونية / كلية القانون - جامعة بغداد العدد الخاص الثالث- الجزء الثاني / $r+1 V$

تنظر الهيئة التمييزية في العريضة التمييزية التي يقدمها المييز من الناحية الشكلية اولا ثم تنظرها من الناحية الموضوعية وتقرر وفقا للاتي :

$$
\begin{aligned}
& \text { ا- الغاء القرار التمييزي } \\
& \text { r- رد التمييزوتاييد القرار الاستئنافي } \\
& \text { ب- ت تعديل القرار المميز }
\end{aligned}
$$

1- الغاء القرار المميز:. اذا ما وجدت الهيئة التمييزية ان القرار المميز مستوفي شروطه من

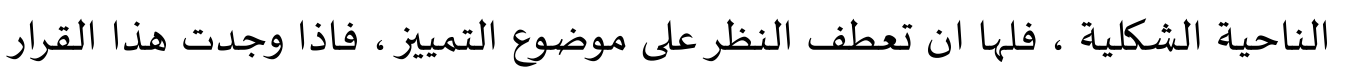
قد بنى على مخالفة القانون او خطا في تطبيقه اوعيب في التاويل او مخالفة من حيث

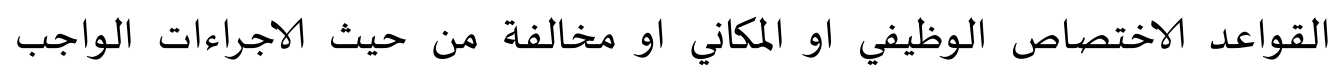
اتباعها في اصدار القرار الاستئنافي ، او سبق الفصل في الدعوى او وقوع خطا جوهري في القرار الاستئنافي ، عندها للهيئة التمييزية ان تقرر الغاء القرار الاستئنافي. r- تاييد القرار الاسئنافي :. ان تخلف احد الشروط التمييز السابق ذكرها ، فالهيئة التمييزية ان ترد التمييز وتاييد القرار الاستئنافي دون ان تنظر في موضهوع القرار الاستئنافي لان هذه الشروط العامة من النظام العام ( كان يقوم المكلف بتمييزه قرار السلطة المالية امام هيئة التمييز مباشرة قبل اللجوء الى الاستئناف امام هيئة

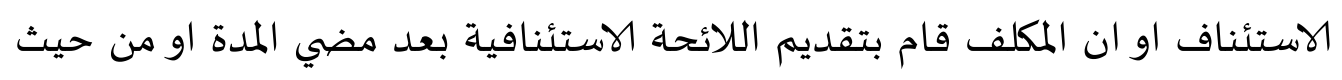
المبلغ الضريبة ( . . . ( ) عشرة الاف دينار او اقل من عشرة الاف دينار . يرى الكتاب عدم عدالة هذا الشرط لانه يحق للمكلف ان يطعن في قرار اللجنة

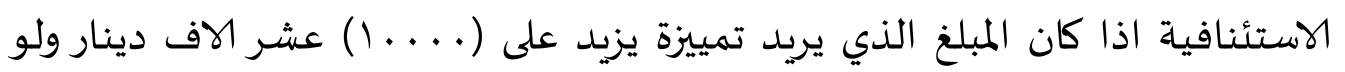
بمبلغ ضئيل هو (1 . . 1) دينار ويفضل ان يتم الطعن بقرارات اللجنة الاستئنافية مهما كان مبلغ الضريبة ، كما ان للهيئة التمييزية ان تقرر رد التمييزوتاييد القرار المييز رغم من توافر جميع الشروط الشكلية اذا تبين لها ان المييز لم يورد اسباب لطعنه او

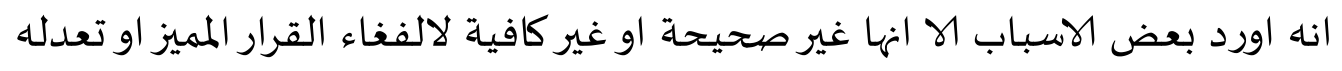


مجلة العلوم القانونية / كلية القانون - جامعة بغداد العدد الخاص الثالث- الجزء الثاني / $r+1 V$

، وتقرر الهيئة التمييزية رد الطعن التمييزي شكلا حال طلب السلطة المالية (المميز) سحب اللائحة التمييزية عند الاتفاق بين الاطراف النزاع ، فلا يوجد مبرر تمييز.

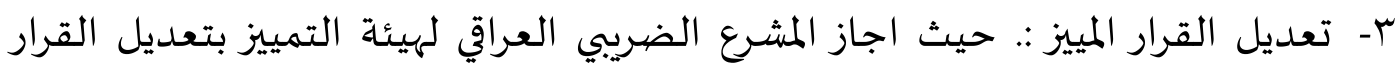

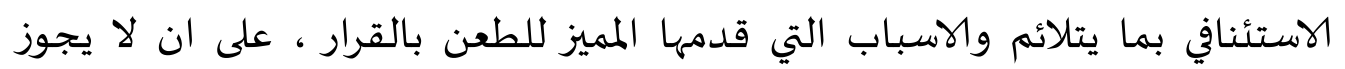

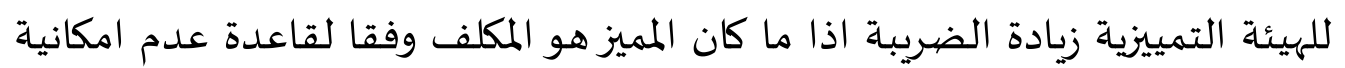
التضرر الطاعن بطعنه ، وكذلك لا يجوز لهيئة التميز بتخفيض التقدير اذا ما كان

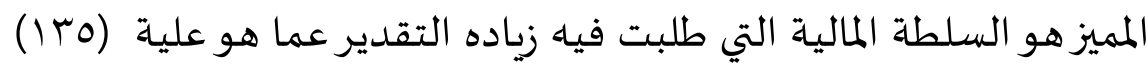

تعد قرارات الهيئة التميزية قطعية بمجرد صدورها ولايجوز لاي جهة المساس بها

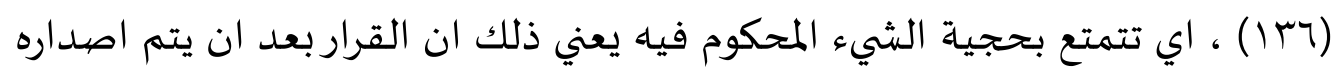

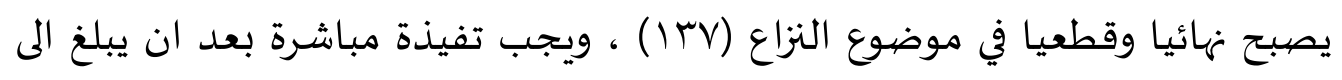
السلطة المالية والكلف (مبا )

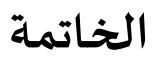

في هاية هذه الدراسة لابد لنا ان نحدد اهم الاستنتاجات والمقترحات وكالاتي :اولا:- الاستنتاجات انهينا في هذه الدراسة الى مجموعاه من الاستنتاجات اهمها :-

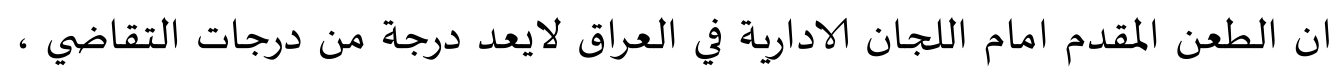
ولا تعدو ان تكون تظلمات ادارية ، وتخويل لجان الطعن الضريبي الادارية صلاحية نظر الطعون الضريبية ولكن من دون اهدار مبدئ استقلال القضاء او الحق في التقاضي ونجد ان التجربه التشريعية والقضائية المصرية في نطاق ترتيب مراحل الطعن الضريبي والجهات التي تحسمه حفاظا على الحق في التقاظي واستقلال القضاء حين اتاح مواصله الطعن الضريبي امام المحاكم وعلى درجتين متجندا في 
مجلة العلوم القانونية / كلية القانون - جامعة بغداد العدد الخاص الثالث- الجزء الثاني /

ذلك المشكلات الدستورية التي تواجه تشكيل لجان الطعن الضريبي على وفق

$$
\text { ثانيا :- التوصيع العراقي وعملها . }
$$

خلصنا من هذه الدراسة الى مجموعة توصيات نتمنى على المشرع العراقي تبنيها وهي:ا- ندعو المشرع الضريبي الى انشاء قضاء ضريبي متخصص بالمنازعات الضريبية يقوده ذو الخبره والاختصاص لتكون احكامه اكثر دقهاه وسرعه ليكون حصن حصين لتحقيق العداله وذلك بتوفير عدد من القضياة المتخصصين للنظر في المنازعات الضريبية ، لتدريههم وتأهيلهم مما يوفر الكفائة والخبرة والدراية بمضوع الضرائب ليتولى صياغة الاحكام المتعلقه بالطعن القضائي بصوره واضحه سهله الفهم من قبل المكلفين ومع التأكيد على الاسراع في نظر

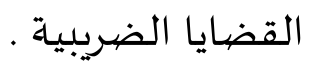

r- ان توفير الضمانات الكافية للمكلف في قانون ضريبة الدخل العراقي التي تحمله الى الاتجاه للقضاء الضريبي بثقة وقناعة وتفعيل عمل اللجان الضريبية والتأكيد على استقلاليتها ومعالجة جميع المعوقات التي يعاني منها هذا الجهاز القضائي بصوره عامه واللجان الضريبية بصورة خاصية . r- نشر الوعي الضريبي لدى لمكلف مما يوفر الثقة بين المكلف والادارة الضريبية

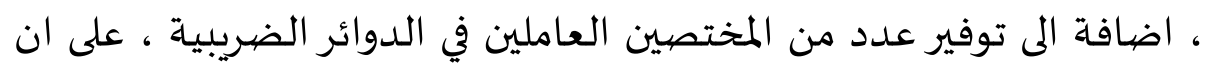
يتم تأهيل هذه الكوادر من خلال دورات لهم بهدف تعليمهم بالمسائل القانونية وشرح قوانين الضرائب ،على ان تتم تزويد الدوائر الضريبية بمستلزمات التكنلوجه لتطوير عملهم داخل دوائر الضرائب. ع- لابد من اتباع الاصول الخاصها بعمل اللجان الضريبية تتلائم وطبيعة عمل هذه اللجان التي تتسم بالسرعة والسرية وذلك بالتأكيد على التزام موظفي

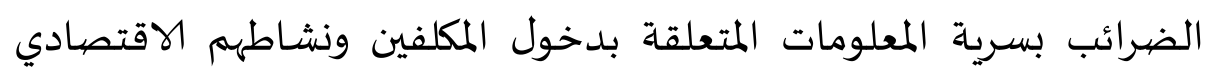
مما يولد الثقة بالدائرة الضريبية من قبل المكلف . 
مجلة العلوم القانونية / كلية القانون - جامعة بغداد العدد الخاص الثالث- الجزء الثاني /

0- الغاء المادة (00) من قانون ضريبية الدخل المرقم برا1 لسنة ب1919 المعدل والغاء قانون رقم (.1) لسنة V. . . الذي اعادة العمل بها وذلك عن طريق

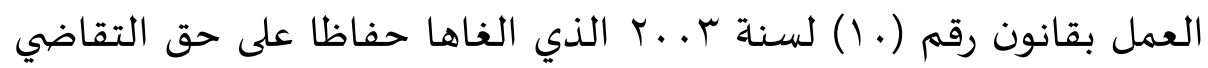
الذي كفله الدستور في المادتين ( . . 19,1) ، مع الاشارة الى عدم زيادة تقدير الضريبة في المرحلة الاستئنافية لكونها تخالف قاعة اساسية في نظام التقاضي ( عدم جواز اضرار الطاعن بطعنه).

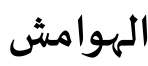

انظر عبد الرحمن قاسم ابراهيم دقه ، العدالة الضريبية في مشروع

قانون ضريبة الدخل الفلسطيني ، رساله ماجستير مقدمة لجامعة النجاح ،

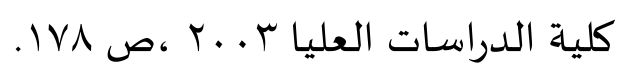

انظر احمد فارس عبد العزاوي ـ الحماية القانونية للمكلف الضريبي

في القانون العراقي ـ رسالة دكتوراه مقدمة الى جامعة تكريت ، كلية القانون ،

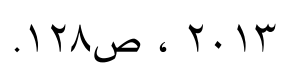

انظر رجاء محمد خويلد ، الطعن القضائي في منازعات ضريبة الدخل

في فلسطين ، رسالة ماجستير مقدمه الى جامعة النجاح بغزة ، كلية

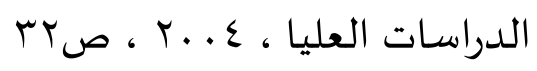

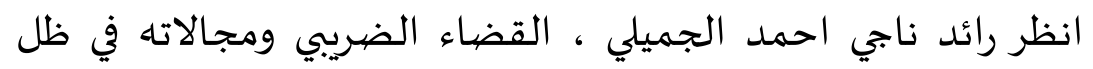

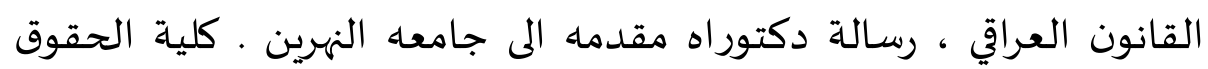

$$
\text { Ver r... \&. }
$$

انظر المعجم الوسيط ، مجمع اللغة العربية ، الجزء الاول ، مادة

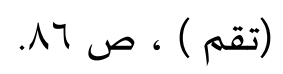


مجلة العلوم القانونية / كلية القانون - جامعة بغداد العدد الخاص الثالث- الجزء الثاني /

انظر رعد شمس الدين الكيلاني ، القضاء في بيت المقدس في العصر

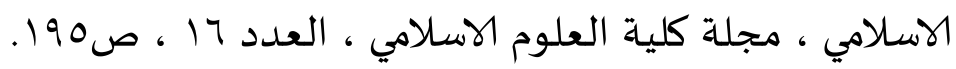

انظر ابي الحسن بن عبد محمد بن حبيب الماوردي ، الاحكام

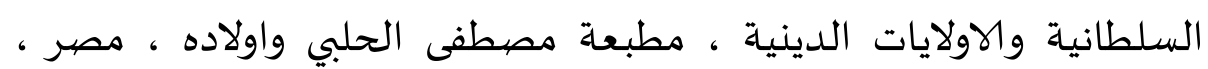

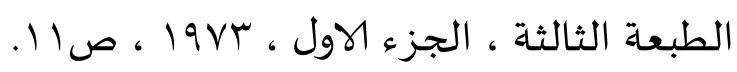

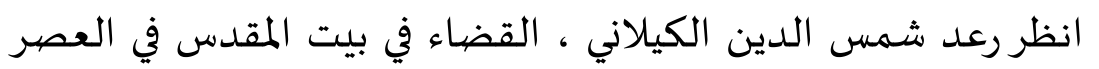

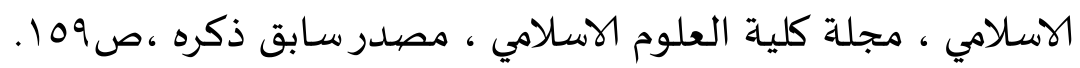

انظر مصطفى محمد عطية ، احكام مشروعية القضاء دراسة

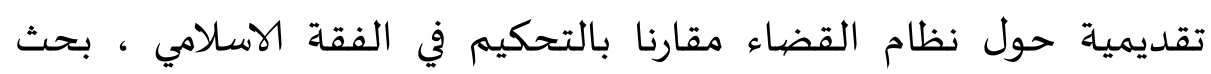

$$
\text { منشور على الموقع. }
$$

(.) انظر جعفر السيجاني ، القضاء والشهادة في الشريعة الشلامية

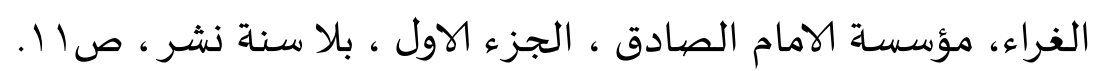

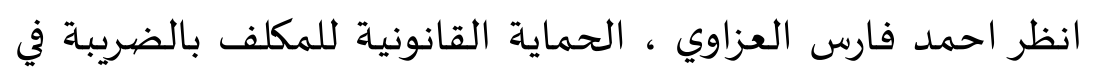

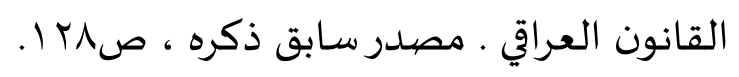

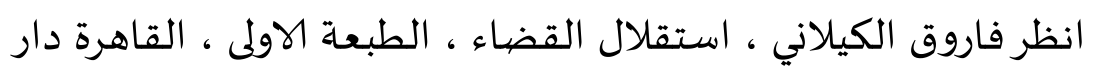

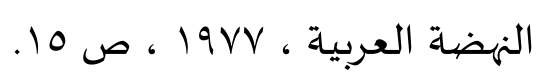

انظر حسن كيره ، المدخل الى القانون ، الاسكندرية ، منشاه المعارف

$$
\text { . TIEص، 19VE。 }
$$

انظر عبد المنعم البدراوي ،المدخل للعلوم القانونية ، بيروت ، دار

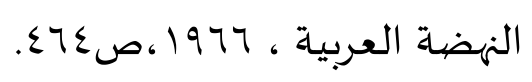

(10) انظر دريد عيسى ابراهيم الخالدي ،مبدأ المساواة امام الضريبه وتطبيقاته ،رسالة ماجستير مقدمة الى جامعة الانبار ، كلية القانون

$$
\text { IVA. T. IT. }
$$


مجلة العلوم القانونية / كلية القانون - جامعة بغداد العدد الخاص الثالث- الجزء الثاني /

انظر رائد ناجي احمد الجميلي ، القضاء الضريبي ومجالاته في ظل

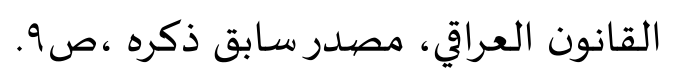

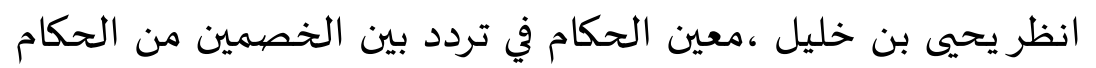

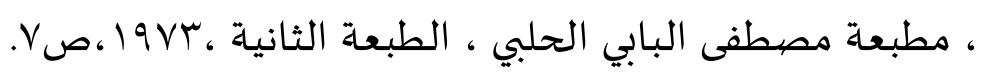

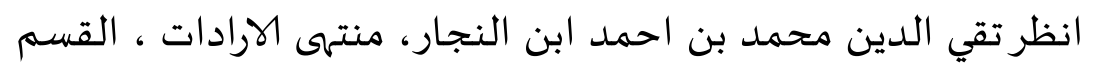

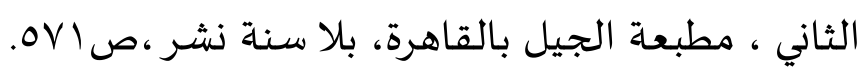

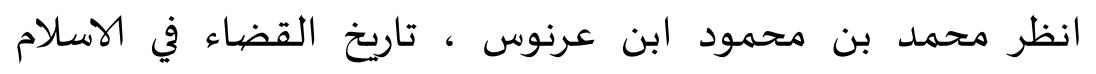

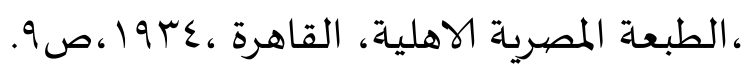

انظر محمد عصفور ،استقلال السلطة القضائية ،القاهرة ،بلا دار

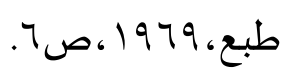

انظر منير حميد البياتي ، النظام السياسي الاسلامي مقارنا بالدولة

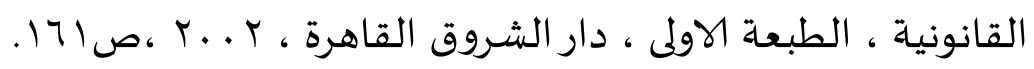

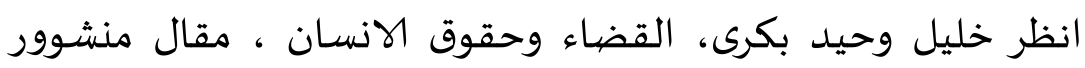

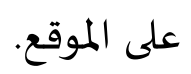

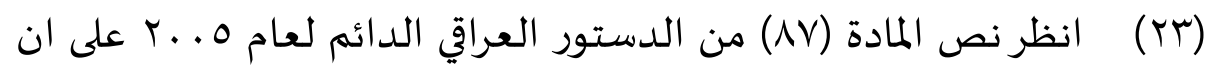

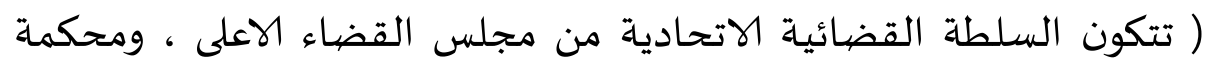
الاتحادية العليا ، ومحكمة التميز الاتحادية ، وجهاز الادعاء العام ،وهيئة الاشراف القضائي، والمحاكم الاتحادية الاخرى التي تنظم وفقا للقانون). انظر منصور حاتم وهادي حسين ، الاثر الاجرائي للواقع والقانون في تحديد وصف محكمة التميز ، بحث منشور في مجلة المحقق الحلي ، جامعة

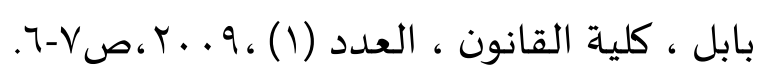

انظر شهاب الدين ابو العباس بن ادريس القراقي ، الاحكام في تمييز

الفتاوي من الاحكام وتصرفات القاضي والامام ، مطبعة الانوار ، القاهرة ،

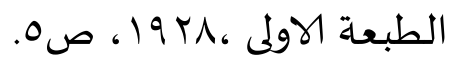


مجلة العلوم القانونية / كلية القانون - جامعة بغداد العدد الخاص الثالث- الجزء الثاني /

انظر صالح محسوب ، السوابق القضائية ودورها في الاستقرار

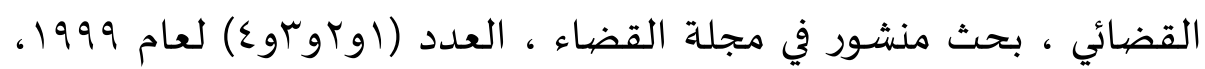

صזr.

انظر بوهان الدين ابو الوفا ابراهيم ، تبصرة الحكام في اصول

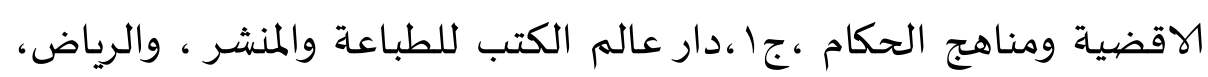

. $V$

انظر حيدر حسن شطاوي ، حياد القاضي الاداري في الدعاوي التي

ينظرها ، بحث منشور في مجلة القادسية للقانون والعلوم والسياسية ،

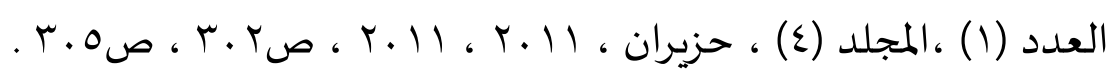

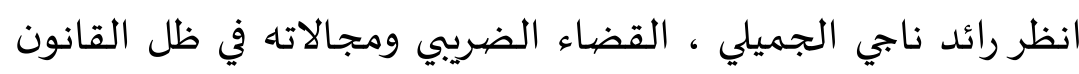

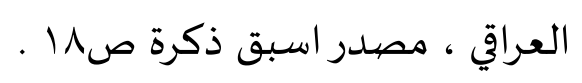

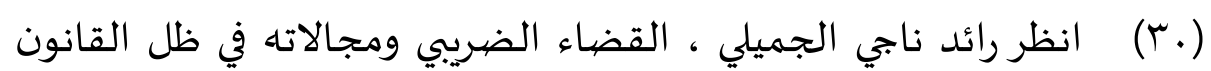

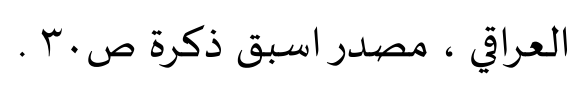

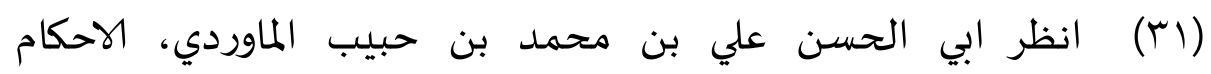

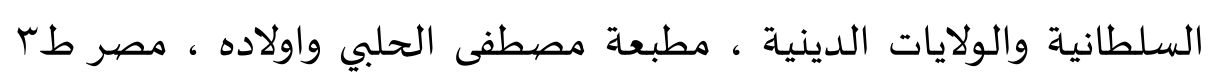

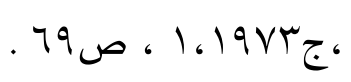

انظر مجي محمد سعد ، الاطار القانوني الممول والادارة الضريبية ،

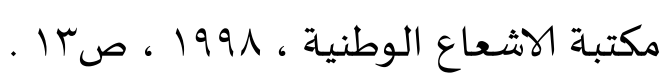

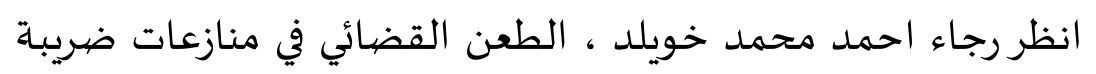

الدخل في فلسطين ، رسالة ماجستير مقدمة الى جامعة النجاح بغزة ،كلية

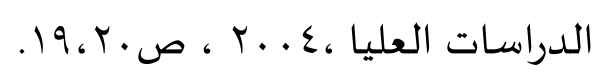

انظر هشام راضي هاشم التايه ، النظام القانوني للادارة الضريبية في

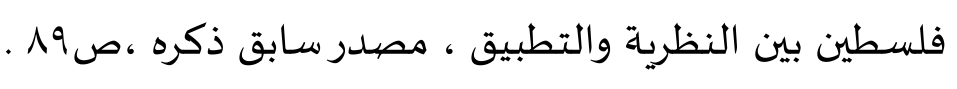


مجلة العلوم القانونية / كلية القانون - جامعة بغداد العدد الخاص الثالث- الجزء الثاني /

انظر جمال ابو يونس ، ادارة الضرائب المباشرة في فلسطين (من عام

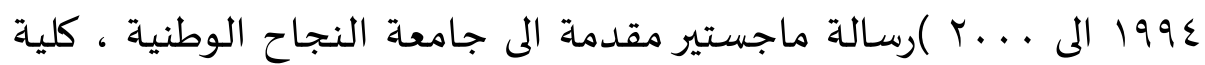

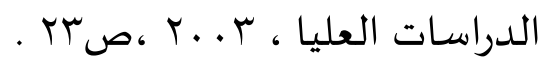

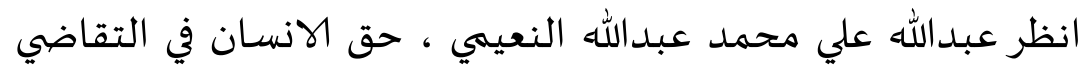
في الشريعة الاسلامية والقانون الوضعي (دراسة مقارنة ) ، رسالة ماجستير

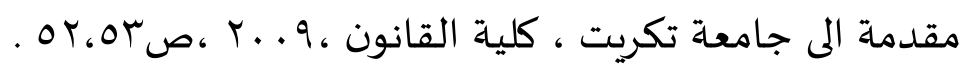
(TV) انظر فؤاد العطار ، النظم الساسية والقانون الدستوري ، دار النهضة

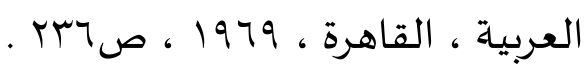
انظر هشام راضي هاشم التايه ، النظام القانوني للادارة الضريبية في فلسطين بين النظرية والتطبيق ، مصدر سابق ذكره ،صلحاب. (19) انظر محمد انس قاسم جعفر ، الرقابة على دستورية القانون

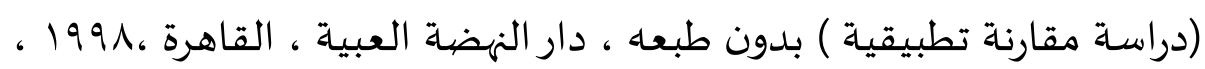
( انظر رجاء احمد محمد خويلد ، الطعن القضائي في منازعات ضريبة الدخل في فلسطين ، رسالة ماجستير مقدمة الى جامعة النجاح بغزة ،كلية

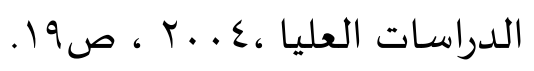

انظر مجي محمد سعد ، الاطار القانوني الممول والادارة الضريبية ،

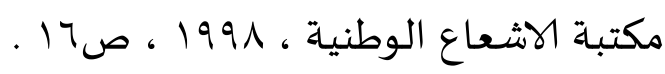
انظر رائد ناجي الجميلي ، القضاء الضريبي ومجالاته في ظل القانون

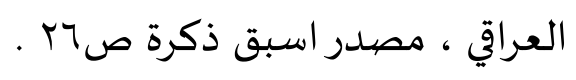

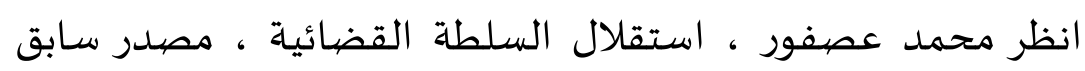

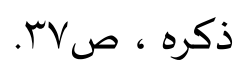

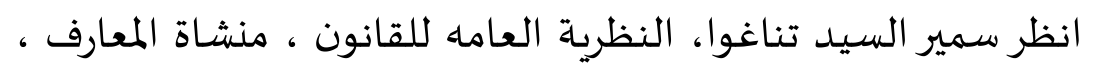

$$
\text { الاسكندرية ، بت ، صזمع. }
$$


مجلة العلوم القانونية / كلية القانون - جامعة بغداد العدد الخاص الثالث- الجزء الثاني /

انظر عزيز كاظم جبر الخفاجي ، مقارنة بين الفقة والقضاء والتشريع

،بحث منشور في مجلة الكوفه ،صرم.

انظر رجاء احمد محمد خويلد ، الطعن القضائي في منازعات ضريبة

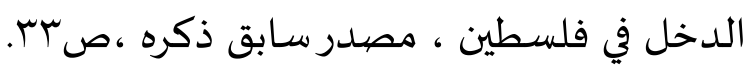

انظر عادل فليح العلي ، المالية العامه والقانون المالي والضريبي مصدر ، بهر

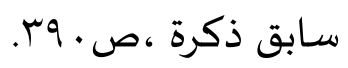

(乏) ( انظر مجي محمد سعد ، الاطار القانوني للعلاقة بين الممول والادارة

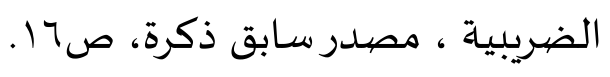

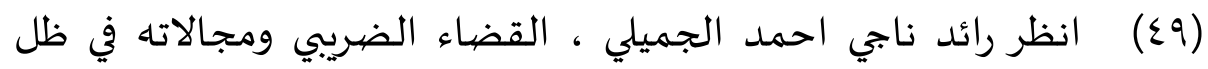

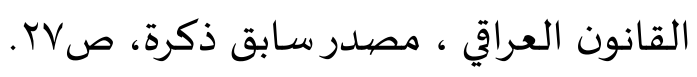

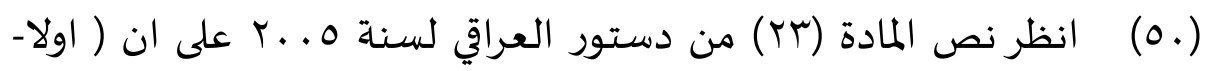
الملكية الخاصة مصونه ، ويحق للمالك الانتفاع بها واستغلالها والتصرف بها لهريا ، في حدود القانون .ثانيا- لايجوز نزع الملكية الا لاغراض المنفعة العامه مقابل تعويض عادل وبنظم ذلك بقانون .ثالثا- أ_ للعراقي الحق في تملك في أي مكان في العراق ، ولا يجوز لغيرة تملك غير المنقول ، الا ما استثنى بقانون .بـ يحظر التملك لاغراض التغيير السكاني ) . (0) انظر رجاء احمد محمد خويلد ، الطعن القضبائي في منازعات ضريبة

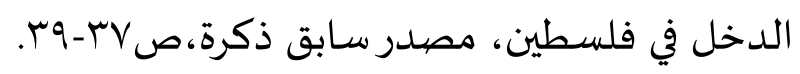

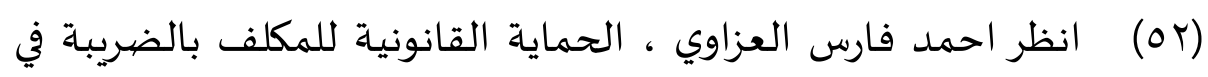

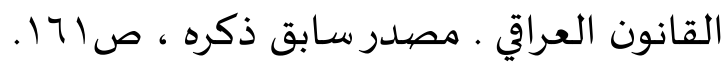
(Or) انظر رجاء احمد محمد خويلد ، الطعن القضائي في منازعات ضريبة

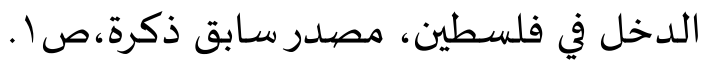

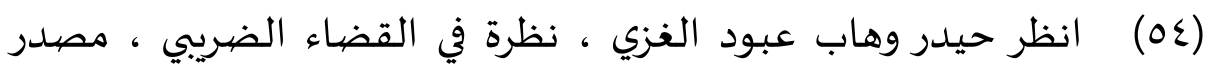

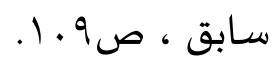


مجلة العلوم القانونية / كلية القانون - جامعة بغداد العدد الخاص الثالث- الجزء الثاني /

(00) انظر علي هادي عطية الهلالي ، مدى ذاتية الاثبات في المنازعات الضريبية ، مصدر سابق ذكره ،صم . (07) انظر احمد فارس عبد العزاوي ـ الحماية القانونية للمكلف الضريبي في القانون العراقي ـ رسالة دكتوراه مقدمة الى جامعة تكريت ، كلية القانون ،

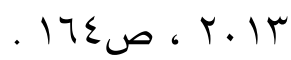
(ov)

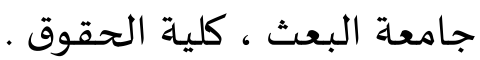

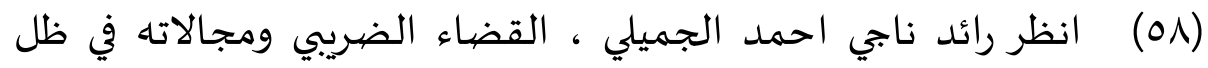
القانون العراقي ، مصدر سابق ذكرة، ص rr .

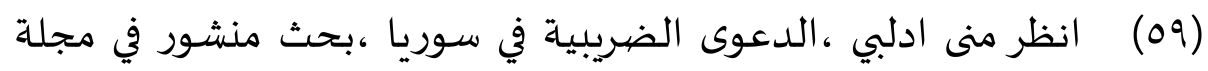
جامعة دمش للعلوم الاقتصادية والقانونية ،دمشق ، المجلد (YV) ، r.1I

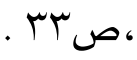

انظر علي هادي عطية الهلالي ، مدى ذلتية الاثبات في المنازعات

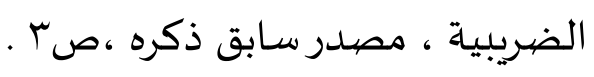

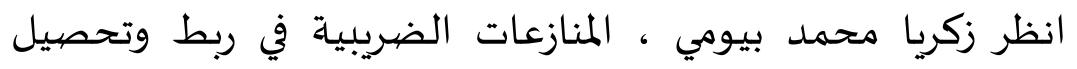

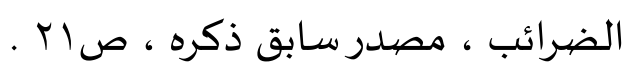

انظر مصطفى كمال وصفي ، مجلس الدولة القاضي العام للمنازعات

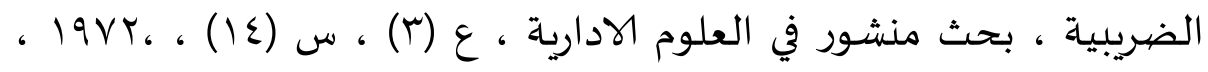

$$
\text { . VV.V ص }
$$

انظر رجاء احمد محمد خويلد ، الطعن القضائي في منازعات ضريبة

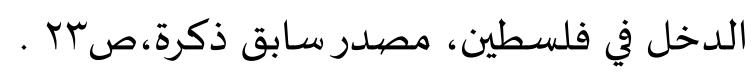

انظر شمس الدين محمد بن ابي العباس احمد بن حمزة الرملي ،

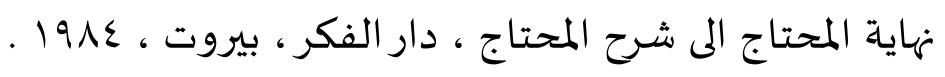


مجلة العلوم القانونية / كلية القانون - جامعة بغداد العدد الخاص الثالث- الجزء الثاني /

انظر محمد حمزة الزبيدي ،تاج العروس من جواهر القاموس ،دار بيروت مكتبة الحياة .

انظر رجاء احمد محمد خويلد ، الطعن القضائي في منازعات ضريبة

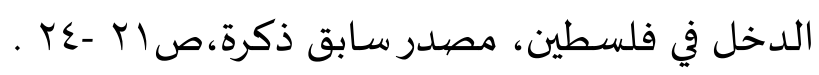

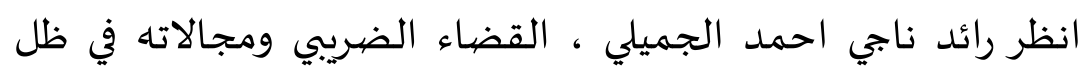

$$
\text { القانون العراقي ، مصدرس سابق ذكرة، ص سب. }
$$

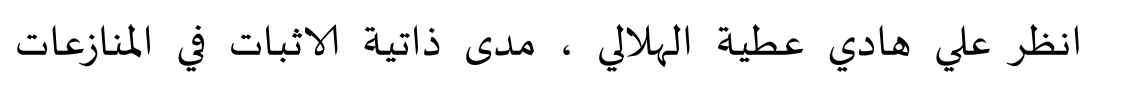

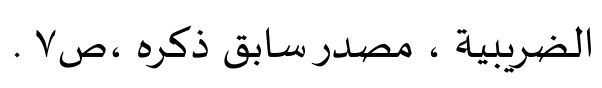

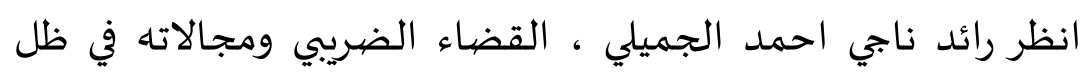

$$
\text { القانون العراقي ، مصدر سابق ذكرة، ص بr. }
$$

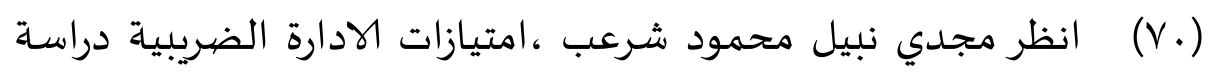

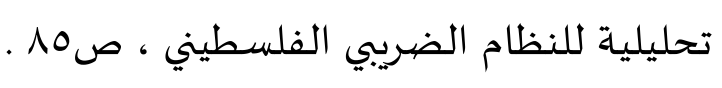

انظر عدوان معزوز محمد مشيته ،مسببات النزاع في قانون ضريبة (VI)

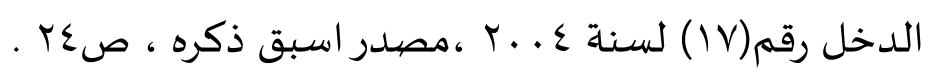

انظر علي هادي عطية الهلالي ، مدى ذاتية الاثبات في المنازعات (VT)

$$
\text { الضريبية ، مصدر سابق ذكره ،صلول }
$$

(VT)

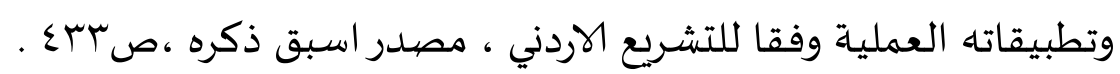

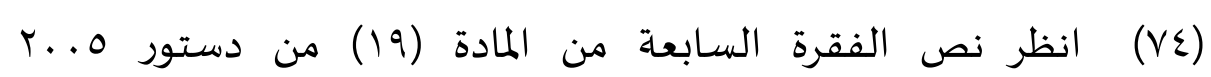

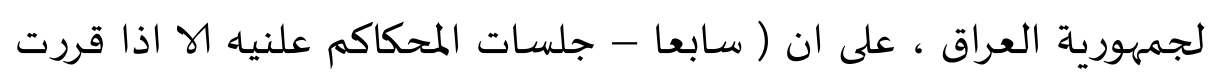

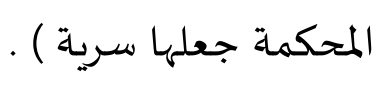

(Vo) انظر نص المادة (0) من قانون التنظيم القضائي رقم (.7 (1) لسنة 
مجلة العلوم القانونية / كلية القانون - جامعة بغداد العدد الخاص الثالث- الجزء الثاني /

(VT) في الشريعة الاسلامية والقانون الوضعي (دراسة مقارنة ) ، رسالة ماجستير

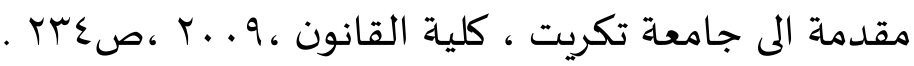
انظر رائد ناجي احمد الجميلي ، القضاء الضريبي ومجالاته في ظله (VV) القانون العراقي ، مصدر سابق ذكرة، ص ر؟ّ. (VN)

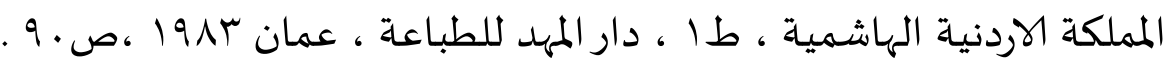
(V9)

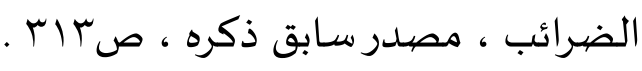

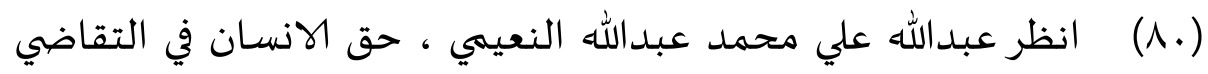

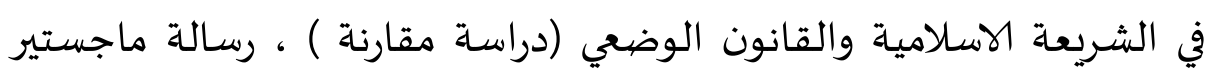

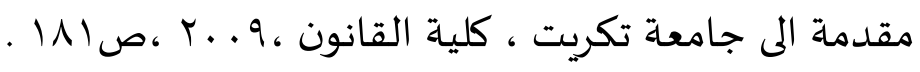

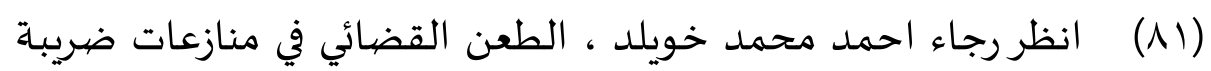
الدخل في فلسطين ، مصدر سابق ذكره ،صوحس.

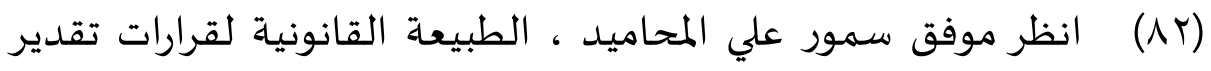
ضريبة الدخل ( دراسة مقارنة الردن ، مصر ، الولايات المتحدة الامريكية )

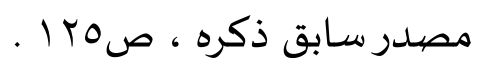
(Ar) ضريبة الدخل بان اعضائها من الموظفين الاداريين لذلك تعد جهالت ادارية بحته انظر مدحت عباس امين ، ضريبة الدخل في التشريع العراقي( دراسة

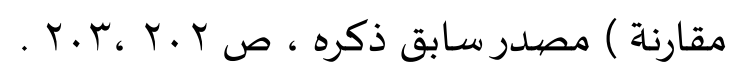

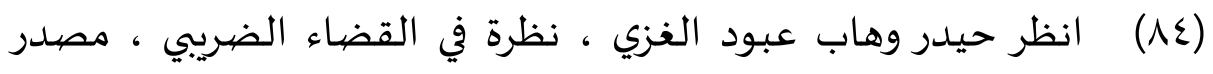

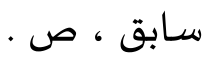


مجلة العلوم القانونية / كلية القانون - جامعة بغداد العدد الخاص الثالث- الجزء الثاني /

(10) (انظر رائد ناجي احمد الجميلي ، القضاء الضريبي ومجالاته في ظل القانون العراقي ، مصبدر سابق ذكرة، ص . V . .

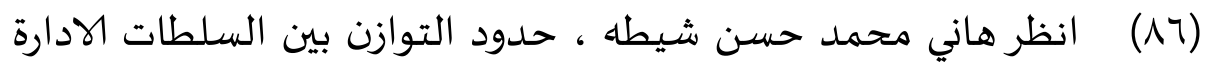
الضريبية وضمانات المكلفون ،ةمصدر سابق ذكره ، صهاب. انظرعلي هادي عطية ، مشروعية اختصاص اللجان الادارية في نظر $\quad$ (NV) الطعون الضريبية ودستوريته ونطاقة ،بحث منشور في مجلة القانون للدراسات والبحوث القانونية ، كلية القانون ، جامعة ذي قار

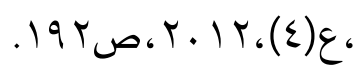
انظر دريد عيسى ابراهيم الخالدي ،مبدأ المساواة امام الضريباه (NA) وتطبيقاته ،مصدر سابق ذكره ،صال11. (19) (19) القانون العراقي ، مصدر سابق ذكرة، ص عVI ا ل . انظر موفق سمور علي المحاميد ، الطبيعة القانونية لقرارات تقدير ضريبة الدخل ( دراسة مقارنة الاردن ، مصر ، الولايات المتحدة الامريكية ) مصدر سابق ذكره ، صVY ا.رائد ناجي احمد الجميلي ، القضاء الضريبي ومجالاته في ظل القانون العراقي ، مصدر سابق ذكرة، ص • IV . انظر عادل احمد حشيش، الوسيط في الضرائب على الدخل، مصدر سابق ذكره ،صو79ء. (ب79. انظر عبد الله محمود امين ، تقويم فاعلية نظام التحاسب الضريبي

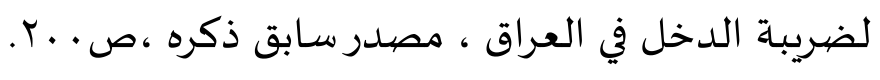

(ج) انظر ضامن حسين العبيدي ،المجالس واللجان الادارية ذات ذات الاختصاص القضائي في العراق ،رسالة ماجستير مقدمة الى جامعة بغداد

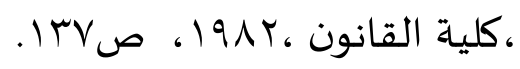


مجلة العلوم القانونية / كلية القانون - جامعة بغداد العدد الخاص الثالث- الجزء الثاني /

انظر رائد ناجي احمد الجميلي ، القضاء الضريبي ومجالاته في ظل القانون العراقي ، مصبدر سابق ذكرة، ص . V . . وصف المشرع العراقي المنازعات الضريبية المعروضة ( بالعريضة ) ولم دهره يوصفها بالدعوى ، وان الجهات التي تنظرها ليست محاكم على وفق قانون

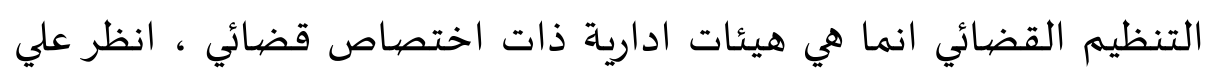

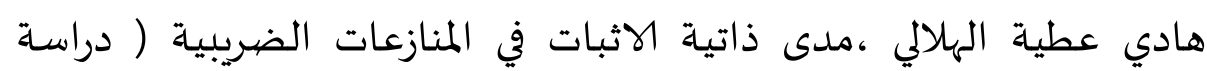
مقارنه) ، مصدر سابق ذكرة ،ص0.

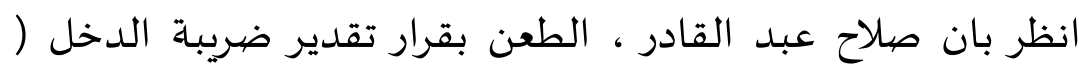

$$
\text { دراسة مقارنه )،مصدر سابق ذكرة ،صعـ ال. }
$$

انظر رائد ناجي احمد الجميلي ، القضياء الضريبي ومجالاته في ظل

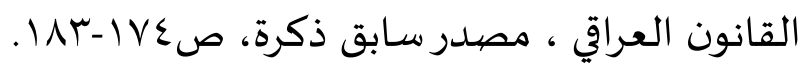

انظر دريد عيسى ابراهيم الخالدي ،مبدأ المساواة امام الضريبه هرديه

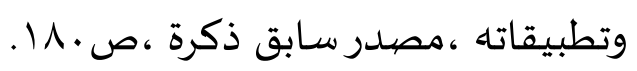

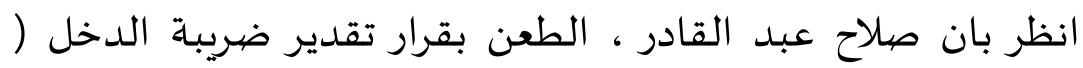

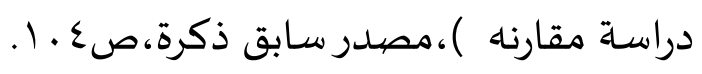

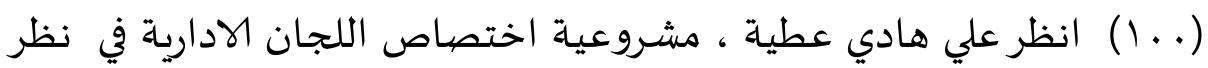
الطعون الضريبية ودستوريته ونطاقة، مجلة القانون للدراسات والبحوث

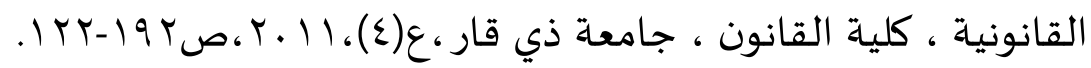
(1 ـ (1) انظر خالد لفته شاكر ، الاختصاص القضائي للادارة في غير منازعات الوظيفة العامه ، رسالة دكتوراه مقدمة الى جامعة بغداد ، كلية القانون

$$
\text { .1. 1-1.7. 1994. }
$$

(r (1) انظر احمد فارس عبد العزاوي . الحماية القانونية للمكلف الضريبي

$$
\text { في القانون العراقي، مصددر سابق ذكرة ،ص . عـأ. }
$$


مجلة العلوم القانونية / كلية القانون - جامعة بغداد العدد الخاص الثالث- الجزء الثاني /

(r.1) انظر محمد ابراهيم خيري الوكيل ، التظلم الاداري . دار الفكر

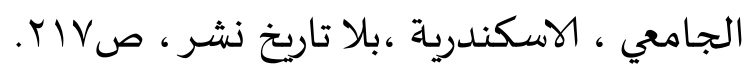

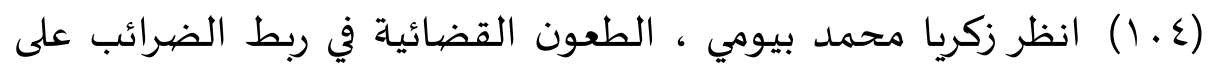

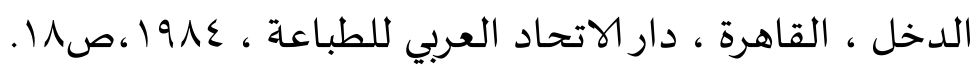
(1.0) انظر احمد خلف حسين الدخيل ، طرق الطعن في تقدير دخل المكلف بضريبة الدخل في العراق ( دراسة مقارنه ) ،مصدر سابق ذكره

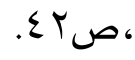
(7 (1) انظر عثمان سلمان غيلان ، مبدأ قانونية الضريبة وتطبيقاتها في تشريع الضرائب المباشرة في العراق ، مصدر سابق ذكرة ،صبساب.

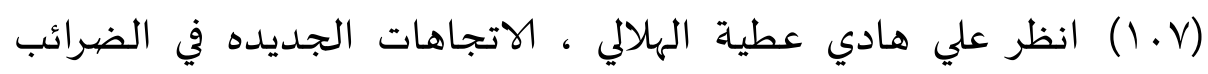
المباشرة ( دراسة قانونية مقارنه) ،مصبدر سابق ذكره ،صهول

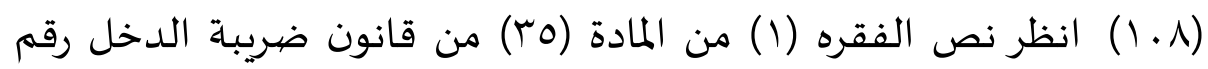
بال لسنة r191 المعدل النافذ ((1- للشخص الذي رفضت السلطة المالية اعتراضها على مقدار الدخل او الضريبة ان يستأنف قرارها لدى لجنة التدقيق بعريضه يقدمها اليه او الى اية دائرة من دوائر الهيئة العامه للضرائب خلال واحد وعشرون يوما من تاريخ تبليغه برفض اعتراضها ،

$$
\text { وعلية ان يثبت ذلك بالوثائق والسجلات والبيانات الاخرى ). }
$$

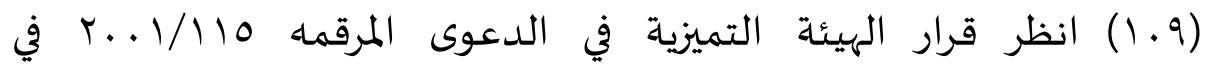

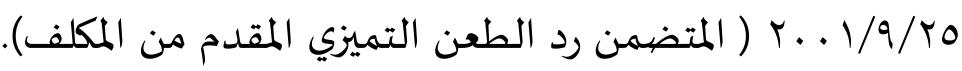

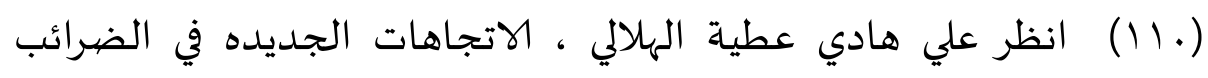

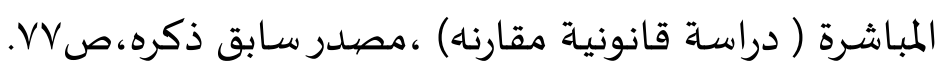

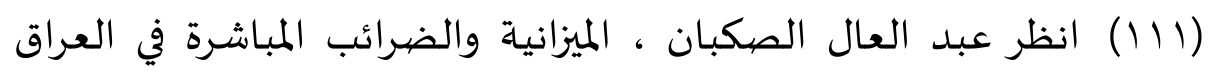

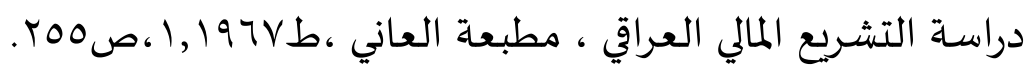


مجلة العلوم القانونية / كلية القانون - جامعة بغداد العدد الخاص الثالث- الجزء الثاني /

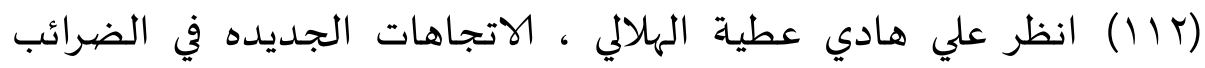

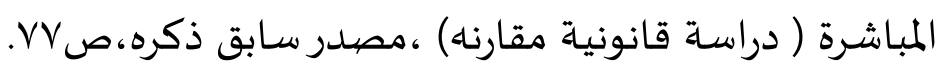
(r/1) انظر نص المادة (عץ) على انه : ( اذا تم الاتفاق بين المعترض والسلطة المالي على تقدير الدخل او قدم الاعتراض بعد المدة القانونية ولم توافق السلطة المالية على تمديدها يصبح التقدير قطعيا ولايقبل الاعتراض ) انظر احمد خلف حسين الدخيل ، طرق الطعن في تقدير دخل المكلف بضريبة الدخل في العراق (دراسة مقارنه) ، مصدر سابق ذكره ،صـه

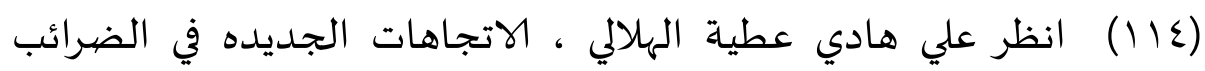

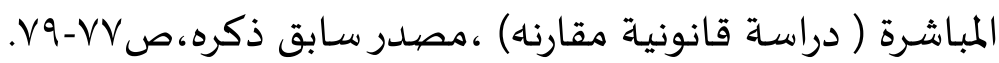
(110) انظر نص الفقره (1) من المادة (1\%) من قانون ضريبة الدخل رقم rا1/ لسنة r191 المعدل النافذ ((1 للشخص الذي رفضت السلطة المالية اعتراضها على مقدار الدخل او الضريبة ان يستأنف قرارها لدى لجنة التدقيق بعريضها يقدمها اليه او الى اية دائرة من دوائر الهيئة العامه للضرائب خلال واحد وعشرون يوما من تاريخ تبليغه برفض اعتراضها ، وعلية ان يثبت ذلك بالوثائق والسجلات والبيانات الاخرى )، انظر عثمان سلمان غيلان ، مبدأ قانونية الضريبة وتطبيقاتها في تشريع الضرائب المباشرة في العراق ، مصدر سابق ذكرة،صبعץ،،انظر محمد علوم محمد المحمود ، موقف المشرع العراقي من الضريبة على الشركات ،مصيدر سابق ذطرة

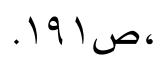
(117) انظر نص المادة (YV) من قانون ضريبة الدخل العراقي النافذ المرقم rا السنة r1911 المعدل على انه ( حذف عنوان (لجان التدقيق) وحل محله عنوان ( لجان الاستئناف وهيئة التميز ) بموجب المادة (V) من قانون تعديل

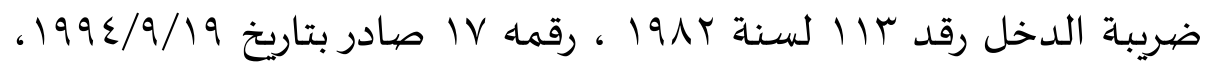

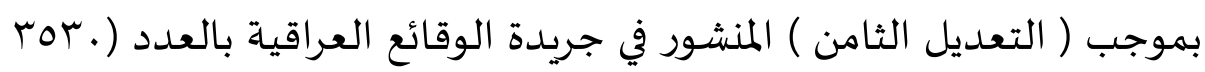


مجلة العلوم القانونية / كلية القانون - جامعة بغداد العدد الخاص الثالث- الجزء الثاني / $r+1 V$

بتاريخ //. 1999 ، وثمة فتوى صدرت عن مجلس شورى الدولة ذهب فيها الى اعتبار لجان التدقيق ( لجان استئناف ) المنصيوص عليها في قانون ضريبة

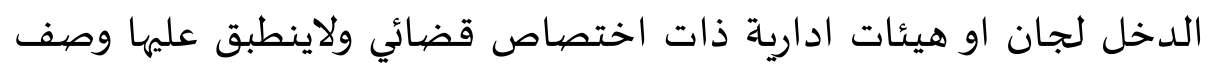
المحاكم منشورة في الكتاب السنوي ، وزارة المالية ، الهيئة العامه للضرائب

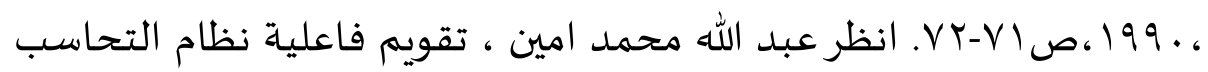
الضريبي لضريبة الدخل في العراق ، رسالة دكتوراة مقدمة الى جامعة

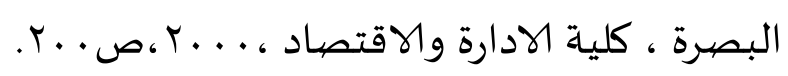

انظر سوزان عثمان قادر ، الضريبة على نقل ملكية العقار او نقل (IIV) حق التصرف فيه في ظل قانون ضريبة الدخل العراقي رقم (rا () لسنة

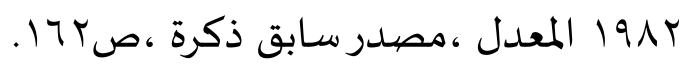

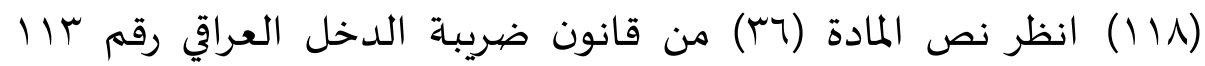
لسنة r1919 المعدل على انه ( يبلغ المستأنف والسلطة المالية بيوم المرافعة امام لجنة التدقيق قبل موعده بسبعة ايام على الاقل وعلى الطرفين ان يحضرا امام اللجنه بالذات او بأرسال وكيل عنهما في اليوم والساعة المعينين او ان يبينا اكتفاءهما بالبيانات التحريرية التي قدماها ، وللجنه الغاء التقدير

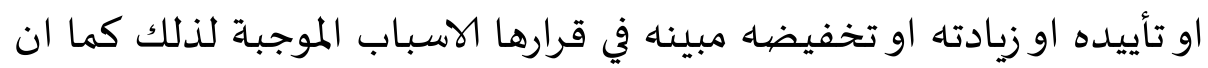

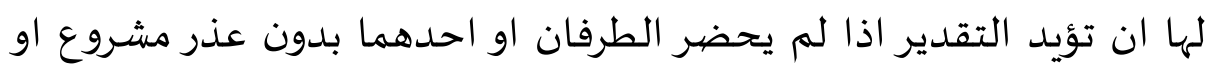
تؤجل النظر في الاستئناف للمدة التي تراها مناسبة ). (119) انظر احمد خلف حسين الدخيل ، طرق الطعن في تقدير دخل المكلف بضريبة الدخل في العراق ( دراسة مقارنه ) ،مصدر سابق

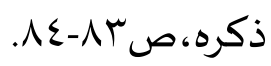

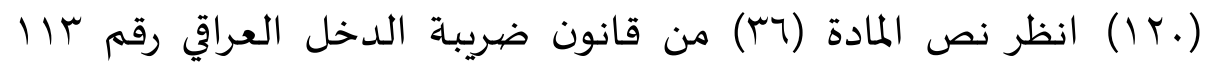
لسنة r1919 المعدل على انه ( يبلغ المستأنف والسلطة المالية بيوم المرافعة امام لجنة التدقيق قبل موعده بسبعة ايام على الاقل وعلى الطرفين ان 
مجلة العلوم القانونية / كلية القانون - جامعة بغداد العدد الخاص الثالث- الجزء الثاني / $r+1 V$

يحضرا امام اللجنه بالذات او بأرسال وكيل عنهما في اليوم والساعة المعينين او ان يبينا اكتفاءهما بالبيانات التحريرية التي قدماها ، وللجنه الغاء التقدير

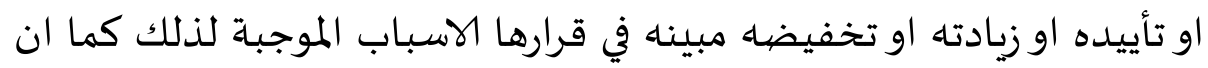
لها ان تؤيد التقدير اذا لم يحضر الطرفان او احدهما بدون عذر مشروع او او تورها تؤجل النظر في الاستئناف للمدة التي تراها مناسبة).

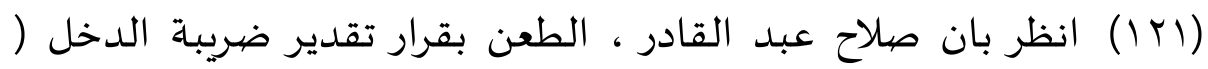

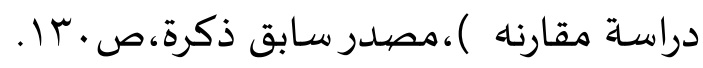

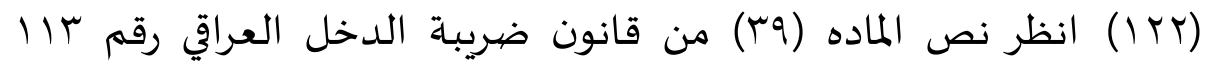
لسنة r1911 المعدل النافذ (ا- تنظر لجان الاستئناف وتبت في كل ما له علاقة بتقدير الدخل وخضوعاه للضريبة والرديات والسماحات وعلى السلطة المالية تنفيذ القرارات بعد تبليغها والى المكلف ). (IT) انظر احمد خلف حسين الدخيل ، طرق الطعن في تقدير دخل المكلف بضريبة الدخل في العراق ( دراسة مقارنه ) ،مصدر سابق ذكره،صrم.

(I) ا I انظر احمد خلف حسين الدخيل ، طرق الطعن في تقدير دخل المكلف بضريبة الدخل في العراق ( دراسة مقارنه ) ،مصدر سابق ذكره،صזم، انظر طاهر الجنابي ، علم المالية العامه والتشريع المالي ، مصدر

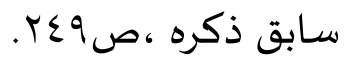

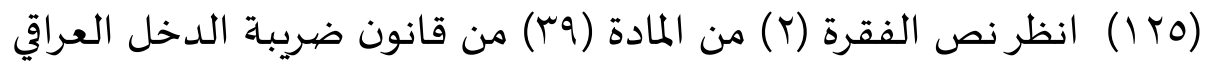

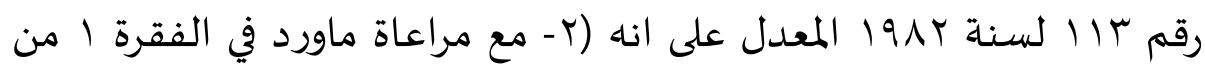
المادة السابعة والخمسين من هذا القانون تخول لجنة الاستئناف النظر في

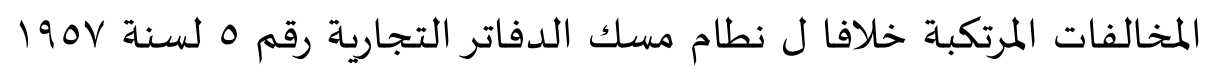
وتعديلاته او أي نظام اخر يحل محله والمحاله الهها من قبل السلطة المالية 
مجلة العلوم القانونية / كلية القانون - جامعة بغداد العدد الخاص الثالث- الجزء الثاني /

وفرض الغرامات المنصوص علهها في النظام وعند عدم دفع الغرامه تحال

القضية الى محكمه المختصة لابدال الغرامه بالحبس).

المصيادر

ا. المعجم الوسيط ، معجم اللغة العربية ، الجزء الاول مادة (تقم) .

الكتب :.

ا. ابي الحسن علي بن محمد بن حبيب المارودي ، الاحكام السلطانية

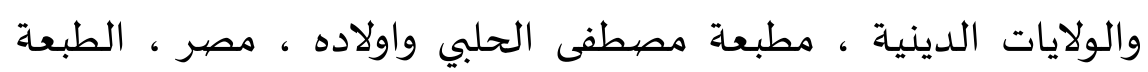

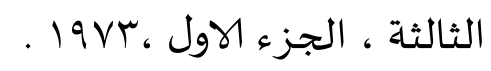

II. احمد خلف حسين الدخيل ، طرق الدخل في تقدير دخل المكلف

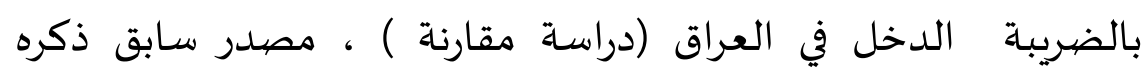
. ص.

III . انظر علي هادي عطية الهلالي ، الاتجاهات الجديدة في الضرائب المباشرة

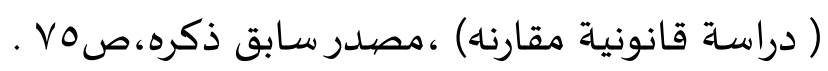

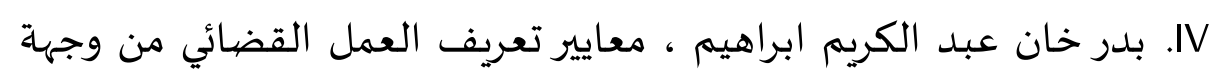

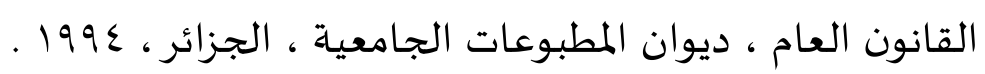

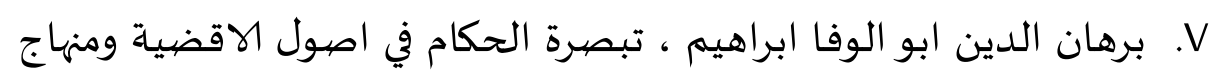

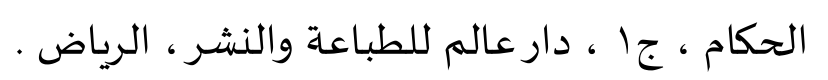

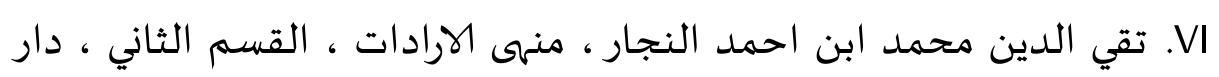

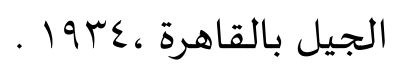

،عفر السيجاني ، القضاء والشهادة في الشريعة الاسلامية الغراء. VII مؤسسة الامام الصادق ، الجزء الاول بلا سنة نشر . 
مجلة العلوم القانونية / كلية القانون - جامعة بغداد العدد الخاص الثالث- الجزع الثاني /

$$
r+1 \mathrm{r}
$$

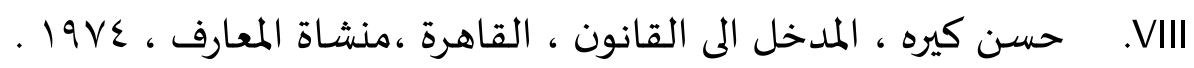

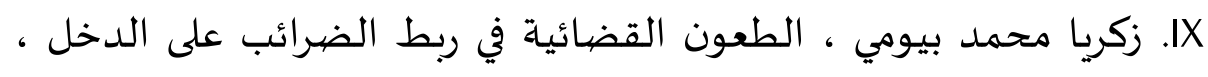

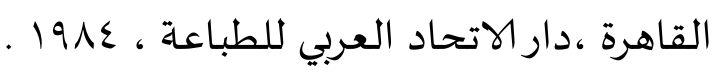

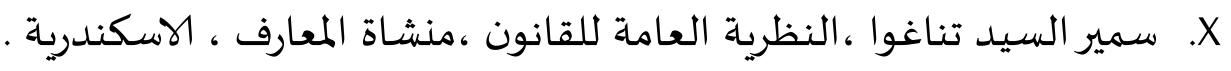

